\title{
THE SYRO-PERSIAN TEXTS IN MANUSCRIPT 398 OF THE CHALDEAN CATHEDRAL IN MARDIN
}

\author{
Mauro Maggi AND PaOla OrsatTi \\ ISTITUTO ITALIANO DI STUDI ORIENTALI \\ UNIVERSITÀ DEGLI STUDI DI ROMA LA SAPIENZA
}

\begin{abstract}
Besides Syriac texts, manuscript 398 of the Chaldean Cathedral in Mardin contains texts in Greek, Armenian, Georgian, Persian, Turkish, and Arabic in Syriac script. This article provides an edition, translation, and philological commentary of its three Persian texts on the basis of this and other witnesses: (1) a Trisagion, also in Mardin 10; (2) an Annunciation hymn with a dialogue between the Angel Gabriel and Mary, partly also in manuscript 94 of the Chaldean Diocese of Alqosh; and (3) a short Palm Sunday hymn, also in Alqosh 94, Deyrulzafaran 197, and Mingana Syr. 184 and 520, previously published on the basis of the Mingana manuscripts only.
\end{abstract}




\section{INTRODUCTION}

The three texts contained in manuscript 398 of the Chaldean Cathedral in Mardin, southeastern Turkey (abridged CCM 398) and partially in manuscript 94 of the Chaldean Diocese of Alqosh, northern Iraq (abridged DCA 94), were kindly brought to our attention by Grigory Kessel. ${ }^{1}$ They are published here with translation and philological commentary.

CCM 398 (= C in the edition below) was copied in 1583 A.D. and is written in Nestorian or East Syriac script. Besides Syriac texts, it contains texts in Greek, Armenian, Georgian, Persian, Turkish, and Arabic in Syriac script. ${ }^{2}$ The Syro-Persian texts are:

1) a Trisagion on f. $244 \mathrm{r} 21-23$;

2) an Annunciation bymn on f. 244v4-17;

3) an untitled Palm Sunday bymn on f. 244v18-22.

DCA 94 (= D in the edition below) is incomplete and is written in East Syriac script. It contains texts in various languages, including Persian on fol. 30v1-4 (Annunciation bymn) and 5-11 (Palm Sunday bymn).

CCM 398 is the only known complete witness of the SyroPersian Annunciation bymn (AH for short, $\ 3.2$ ), which bears the puzzling Syriac title Śurāyà da-qyāmtà Pārsà'it, lit. 'The beginning (?) of resurrection in Persian', and whose liturgical

1 Though this article is the result of close collaboration by its two authors, paragraphs 1 and 3-4 are conventionally by Mauro Maggi and paragraph 2 by Paola Orsatti. Our heartfelt thanks go to Sebastian P. Brock (Oxford) for advice concerning the problematic liturgical contexts and the Syriac elements of the Syro-Persian texts studied here and to Grigory Kessel (Wien), Hidemi Takahashi (Tokyo), and Peter Zieme (Berlin) for providing information concerning the various texts contained in manuscript CCM 398 and discussing some of the problems they pose.

2 See Addai Scher, "Notice sur les manuscrits syriaques et arabes conservés à l'archevêché chaldéen de Diarbékir” (Journal asiatique 10 [1907]), 395-398 ("Cod. 95”); Hidemi Takahashi, "Armenian Garshuni: An overview of the known material" (Hugoye: Journal of Syriac studies 17:1 [2014]), 109-110; and under "CCM 00398" in the Hill Museum \& Manuscript Library online catalogue of manuscripts at https://www.vhmml.org. 
destination and use remain obscure to us (see \3.2). In manuscript DCA 94, only the last verse lines (19-23) are extant.

The Trisagion ( $\mathrm{Tr}$. for short, $\ 3.1$ ) is also preserved in manuscript 10 of the Chaldean Cathedral in Mardin (abridged CCM $10=\mathrm{C}_{1}$ in the edition below), likewise written in East Syriac script and tentatively datable to the 17 th century. ${ }^{3}$

The Palm Sunday bymn (PS for short, $\ 3.3$ ) is also known from other manuscripts besides CCM 398, namely, DCA 94, Mingana Syr. 184 (= B in the edition below; West Syriac script, eighteenth or nineteenth century) and Mingana Syr. 520 (= A in the edition below; West Syriac script, about 1800) of the University of Birmingham, ${ }^{4}$ as well as manuscript 197 of the Deyrulzafaran (Dayr al-Za'farān) Monastery near Mardin (olim Diyarbakır, abridged ZFRN $197=$ Z in the edition below), written in West Syriac script like the two Mingana manuscripts and tentatively datable to the 18th century. ${ }^{5}$ We first published the Palm Sunday bymn on the basis of the two Mingana

3 See Addai Scher, "Notice sur les manuscrits syriaques et arabes conservés dans la bibliothèque de l'évêché chaldéen de Mardin" (Revue des bibliothèques 18 [1908]), 86-87 ("Cod. 81”); Takahashi, "Armenian Garshuni," 86, 98, 109-110; and under "CCM 00010" in the Hill Museum \& Manuscript Library catalogue.

${ }^{4}$ See Alphonse Mingana, Catalogue of the Mingana collection of manuscripts, now in the possession of the Trustees of the Woodbrooke Settlement, Selly Oak, Birmingham, vol. 1, Syriac and Garshüni manuscripts (Cambridge: Heffer and Sons, 1933), 405-408 (no. 184), 956-958 (no. 520) and cf. Mauro Maggi and Paola Orsatti, "Two Syro-Persian hymns for Palm Sunday and Maundy Thursday," in The Persian language in history, ed. Mauro Maggi and Paola Orsatti (Wiesbaden: Ludwig Reichert, 2011), 247-249.

5 See Takahashi, "Armenian Garshuni," 87-88; Idem, "ArmenischGarschuni (Armenisch in syrischer Schrift)," in Scripts beyond borders: A survey of allographic traditions in the Euro-Mediterranean world, ed. Johannes den Heijer, Andrea Schmidt, and Tamara Pataridze (Leuven: Peeters, 2014), 192; Idem, "Armenian Garshuni (Armenian in Syriac characters) and its users," in Syriac in its multi-cultural context: First international Syriac studies symposium, Mardin Artuklu University, Institute of Living Languages, 20-22 April 2012, Mardin, ed. Herman Teule et al. (Leuven: Peeters, 2017), 245; and under “ZFRN 00197” in the Hill Museum \& Manuscript Library catalogue. 
manuscripts ${ }^{6}$ and publish it here again by taking account of all the four so far known witnesses (A, B, C, D, and Z).

Although the Palm Sunday bymn is found in all aforementioned manuscripts (except CCM 10) and the Annunciation bymn of CCM 398 and DCA 94 is linguistically and formally close to the Maundy Thursday bymn (MT for short) known from Mingana Syr. 184, Mingana Syr. 520, ${ }^{7}$ and ZFRN $197,{ }^{8}$ one notices that the Syro-Persian texts in the Mingana and Deyrulzafaran (ZFRN 197) manuscripts, on the one side, and the Mardin and Alqosh manuscripts (CCM 398, CCM 10, and DCA 94), on the other, belong to different orthographic traditions (see $\int 2$ ). This suggests that these liturgical textsamong which the Palm Sunday bymn provides a sort of common denominator-underwent a long and varied manuscript transmission.

The information concerning the aforementioned SyroPersian texts and their witnesses can be summarised thus: ${ }^{9}$

$\begin{array}{lcccc} & \text { Siglum } & \text { Script } & \text { Date } & \text { MT PS AH Tr. } \\ \text { Mingana } & \text { A } & \text { West Syr. } & \text { about } 1800 & + \\ \text { Syr. 520 } & & & & \\ \text { Mingana } & \text { B } & \text { West Syr. } & \text { 18th/19th c.? } & +\quad+ \\ \text { Syr. 184 } & & & & \end{array}$

6 Maggi and Orsatti, "Two Syro-Persian hymns," 250-251 (on form and contents), 266, 271-273 (facsimiles, text, and translation), 282-283 (commentary).

${ }^{7}$ Facsimiles, text, translation, and commentary in Maggi and Orsatti, “Two Syro-Persian hymns," 263-271, 273-282.

${ }^{8}$ On this manuscript, cf. n. 5. The text of the Maundy Thursday bymn in ZFRN 197 is of some interest in that it basically agrees with Mingana Syr. 520 but inserts interlinearly and marginally variants that are in line with and sometines better than those in Mingana Syr. 184 and are mostly written in Arabic script with influence of the Syriac orthography. We will deal with this new witness of the Maundy Thursday hymn in a next article.

${ }^{9} \mathrm{MT}=$ Maundy Thursday bymn

PS = Palm Sunday bymn

$\mathrm{AH}=$ Annunciation bymn

Tr. = Trisagion . 


$\begin{array}{lclcccc}\text { ZFRN 197 } & \text { Z } & \text { West Syr. } & \text { 18th c.? } & + & + & \\ \text { DCA 94 } & \text { D } & \text { East Syr. } & \text { ? } & + & + & \\ \text { CCM 398 } & \text { C } & \text { East Syr. } & \text { copied 1583 } & + & + & + \\ \text { CCM 10 } & \text { C } 1 & \text { East Syr. } & \text { 17th c.? } & & & +\end{array}$

All three Syro-Persian texts in CCM 398 are written on continuous writing lines. In the hymns, dots mark verse lines, that mostly overlap with syntactic units. The Annunciation bymn consists of twenty-three verse lines of 7 to 10 syllables, almost all rhyming in -as (including 2 un(a)s and 12 matar(a)s for standard uns 'intimacy' and matars 'fear not!'). Only two lines rhyme in -ās (5 nās, 7 payd $\bar{a}-s)$. The six Persian verse lines of the short Palm Sunday bymn, which vary apparently from 4 to 9 syllables in length and are followed by a few Syriac lines, likewise all rhyme in -as. The verse structure of the two hymns, especially that of the Annunciation bymn, bears a resemblance to pre-Islamic and early non-Classical Persian versification as outlined by Gilbert Lazard. ${ }^{10}$

The texts under consideration are at times corrupt, which lends support to the hypothesis of a long textual transmission, and display a language variety characterised by non-standard features also to be found in the Maundy Thursday bymn. The occurrence of third singular perfect forms like, for instance, AH $1 \mathrm{~g}^{\mathrm{U}} \mathrm{wp}^{\mathrm{A}} \mathrm{s}$ guftas 'he spoke, ${ }^{11}$ is strikingly frequent and is probably due to the exigencies of rhyme, as the exclusive occurrence of simple past forms in non-rhyme position seems to confirm: AH $12 \dot{\mathrm{g}}^{\mathrm{U}}$ w $\dot{\mathrm{p}} \mathrm{t}$ guft 'he said' and $23 \mathrm{~g}^{\mathrm{U}} \mathrm{w} \dot{\mathrm{p}} \mathrm{t}^{\mathrm{A}} \mathrm{m}$ guftam 'I said' (cf. MT $1 \mathrm{~b}$ rp̈̈, 5b rpt raf(a)t 'they/he went,' 2b, 3b, 6c 'md ämad 'he came, has come,' and 3a giwp $\ddot{t}$ guf(a)t 'he said'). ${ }^{12}$ Spoken or non-classical features are possibly $\mathrm{AH} 8,10$

${ }^{10}$ Cf. the survey in Gilbert Lazard, "Poetry, iv: Poetics of Middle Persian," in Encyclopaedia Iranica, online ed. (2006) with further references.

11 In the manuscripts, the vowel signs are not always aligned consequently with the relevant consonant signs. In the transliteration, their position is standardised in that they precede matres lectionis (the letters ālap, yod, and wāw), but follow full consonant signs.

${ }^{12}$ Cf. Maggi and Orsatti, “Two Syro-Persian hymns," 254. 
$\mathrm{h}^{\mathrm{A}} \mathrm{mj}^{\mathrm{U}} \mathrm{wn}$ hamcun in the meaning 'thus, like that' and the loss of final $-d$ in Tr. $\mathrm{x}^{\mathrm{U}} \mathrm{wd}^{\bar{A}} \mathrm{w}^{\bar{A}} \mathrm{n}$ xudâvan $(3 \times)$ for standard xudàvand 'lord' (see $\int 4$ ). There are some archaic forms as well, such as the preservation of $b$-in PS $4 h^{A} \mathrm{n}$ han for standard an 'that' (but $\mathrm{AH} \mathrm{11,19}{ }^{{ }^{\top} \mathrm{n}} \mathrm{n} \bar{a} n$ ) and, apparently, the preservation of majhūl $\bar{o}$ in $\mathrm{AH} 10 \mathrm{~m}^{\mathrm{A}} \dot{\mathrm{g}}^{\mathrm{O}} \mathrm{w}$ mago 'do not say!', unless this is a slavish, unadapted reproduction of a spelling in the source manuscript (cf. $\int 4$ on $\mathrm{AH} 23 \mathrm{~b}^{\mathrm{A}} \mathrm{d}^{\overline{1}} \mathrm{yd}^{\bar{A}} \mathrm{r}$ padìdar) or a sheer imprecise notation of the back vowel comparable with similar oscillations in the spelling of the front vowels (see $\$ 2$ ). Indeed, the preservation of majhül $\bar{o}$ contrasts strikingly with the change $\bar{e}>\bar{i}$ in $\mathrm{AH} 3 \mathrm{~m}^{\overline{\mathrm{I}}} \mathrm{yd}^{\overline{\mathrm{A}} s} \mathrm{n}^{\mathrm{A}} \mathrm{m}$ midanam, all the more so because we know that the change $\bar{o}>\bar{u}$ preceded the change $\bar{e}$ $>\bar{\imath}$ and not vice versa. ${ }^{14}$

\section{ORTHOgRAPHY OF CCM 398, CCM 10, DCA 94, AND ZFRN 197}

The orthography of the Syro-Persian texts in CCM 398, CCM 10 , and DCA 94 differs from that of the already published texts in Mingana Syr. 184 and 520. ${ }^{15}$ The orthography of ZFRN 197 (PS) hardly requires any comments, as it basically agrees with that of the Mingana manuscripts.

For the notation of vowels, CMM 398, CMM 10, and DCA 94, all in East Syriac script, resort to Syriac vowel points (here transliterated by raised capital letters), ${ }^{16}$ while Arabic vowel signs (transliterated by raised lowercase letters) are only found, in addition to Syriac vowel points, in the two Arabic loanwords $\mathrm{AH} 19 \mathrm{t}^{\mathrm{Aa}} \mathrm{sb}^{\mathrm{I}} \mathrm{y}$ h tasbiḥ 'praise' and $21 \mathrm{C} \mathrm{r}^{\mathrm{Aa}} \mathrm{h}^{\mathrm{I}} \mathrm{ym}$ rahim

13 See Maggi and Orsatti, "Two Syro-Persian hymns," 282.

${ }^{14}$ See Fritz Meier, “Aussprachefragen des älteren Neupersisch” (Oriens 27-28 [1981]), 96-98.

15 See Maggi and Orsatti, “Two Syro-Persian hymns," 255-260.

${ }^{16}$ For their adaptation to the notation of the Persian vowels, see Paola Orsatti, "Syro-Persian formulas in poetic form in baptism liturgy," in Persian origins: Early Judaeo-Persian and the emergence of New Persian: Collected papers of the symposium, Göttingen 1999, ed. Ludwig Paul (Wiesbaden: Harrassowitz, 2003), 150. 


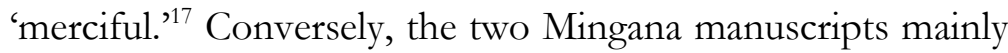
use Arabic vowel signs (ZFRN 197, which pertains to the same orthographic tradition, has zamma in the misspelled variant PS $4 \mathrm{Z} \mathrm{h}^{\mathrm{u}} \mathrm{n}$ for $\mathrm{AB} \mathrm{h}^{\mathrm{a}} \mathrm{n}$ àn 'that', all with sukūn over $\left.-\mathrm{n}\right)$.

The Mardin and Alqosh manuscripts show some inconsistencies in the notation of the Persian vowels, but such inconsistencies are probably devoid of linguistic relevance.

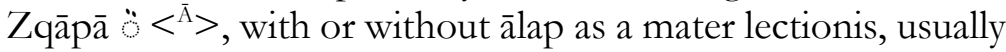
stands for long $\bar{a}$. It occurs for short $a$, instead of ptāhā ${ }^{\mathrm{A}}>$, in the final syllable of Tr. $\mathrm{x}^{\mathrm{U}} \mathrm{wd}^{\bar{A}} \mathrm{w}^{\bar{A}} \mathrm{n}$ xudavan 'Lord' $(3 \times)$ and in the verbal negative prefix $n a-$ in $\operatorname{Tr} . n^{\bar{A}} m^{\mathrm{I}} \mathrm{rd}^{\mathrm{d}} \mathrm{wn}^{\overline{\mathrm{A}}} \mathrm{m}^{\overline{\mathrm{I}}} \mathrm{yr} \mathrm{d}^{\mathrm{A}} \mathrm{d}$ namird va namirad 'he did not die and will not die' (followed by ālap), whereas the negative prefix in PS $5 \mathrm{n}^{\bar{A}} \mathrm{~d}^{\bar{A}} \mathrm{~d}^{\mathrm{A}} \mathrm{s}$ nädädas might actually have been $n \bar{a}$ - before a past participle. ${ }^{18}$ There is an $a$ spelled $<^{\bar{A}}>$ also in AH 5, $15^{{ }^{C} \bar{A}} 1^{A} \mathrm{~m}$ 'álam 'world' (but 22

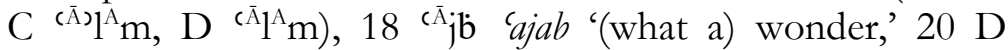

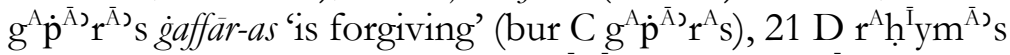
rāhhim-as 'is compassionate' (but $\mathrm{C} \mathrm{r}^{\bar{A}} \mathrm{~h}^{\overline{\mathrm{I}}} \mathrm{ym}^{\mathrm{A}} \mathrm{s}$ ), $22 \mathrm{~h}^{\mathrm{I}} \mathrm{m}^{\overline{\mathrm{A}} \mathrm{s}}$ hima 'all,' $23 \mathrm{~g}^{\mathrm{U}} \mathrm{wpt}^{\mathrm{A}} \mathrm{m}$ guftam 'I have announced', PS $6 \mathrm{C}^{\mathrm{CA}} \mathrm{z}^{\overline{\mathrm{I}}} \mathrm{ym}^{\mathrm{A}} \mathrm{s}$ 'azim-

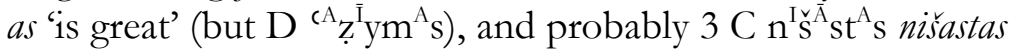
'he is seated' (but $\mathrm{D} \mathrm{n}^{\mathrm{I} s \mathrm{~s}^{A}} \mathrm{t}^{\mathrm{A}} \mathrm{s}$ with displaced ${ }^{\mathrm{A}}$ ).

A similar fluctuation can be observed in the notation of palatal vowels. Normally rbāṣā 'arrīkā $<^{\mathrm{I}}>$ represents a short palatal vowel and hbāṣā,$<{ }^{\overline{1}} \mathrm{y}>$ represents a long $\bar{l}$ (there is no evidence of majhūl ê). However, $\left\langle{ }^{\overline{1}} \mathrm{y}>\right.$ in $\operatorname{Tr}$. $\mathrm{C}_{1} \mathrm{n}^{\overline{\mathrm{A}})} \mathrm{m}^{\overline{\mathrm{I}} \mathrm{yrd}}$ contrasts with $<^{\mathrm{I}}>$ in $\mathrm{C}^{\bar{A}}{ }^{\bar{A}} \mathrm{~m}^{\mathrm{I}} \mathrm{rd}$ namird 'he did not die,' a form which shows a dialectal realisation $i$ of literary short $u$ (namurd)

${ }^{17}$ In the following, reference is made to the readings accepted in the edition below. When reference to specific manuscripts is needed, this is indicated by the addition of the relevant manuscript sigla.

18 This seems to be confirmed by the separate writing of the verbal negative prefix in PS $5 \mathrm{C} \mathrm{n}^{\bar{A}^{\prime}} \mathrm{d}^{\bar{A}} \mathrm{~d}^{\mathrm{A}} \mathrm{S}$ nādādas (here possibly $n \bar{a}$-: see Maggi and Orsatti, "Two Syro-Persian hymns," 255 and 283). The final ālap and, more clearly, the space before the verb show that the prefix was considered as a separate word, as often in Persian texts in non-Arabic scripts. See Ludwig Paul, A grammar of Early Judaeo-Persian (Wiesbaden: Ludwig Reichert, 2013), 116-117\$138. 
characteristic of the language of both $\mathrm{Tr}$. and $\mathrm{AH}$ (see $\int 4$ ). Likewise, there is $<^{\overline{\mathrm{I}}} \mathrm{y}$ for $i$ in $\mathrm{AH} 5 \mathrm{~m}^{\mathrm{U}} \mathrm{wk}^{\mathrm{A}} \mathrm{l}^{\mathrm{I}} \mathrm{yss}$ muxallis 'saviour,' $21 \quad \mathrm{C} \quad \mathrm{r}^{\overline{\mathrm{A}}} \mathrm{h}^{\overline{\mathrm{I}}} \mathrm{ym}^{\mathrm{A}} \mathrm{s}, \quad \mathrm{D} \quad \mathrm{r}^{\mathrm{A}} \mathrm{h}^{\overline{\mathrm{I}}} \mathrm{ym}^{\mathrm{A}} \mathrm{s}$ rāhim-as 'is compassionate,' and possibly in the negative prefix of 11 $\mathrm{n}^{\overline{1}} \mathrm{yd}^{\mathrm{A}} \mathrm{d}^{\mathrm{A}} \mathrm{s}$ nidādas 'did not give' (see $\int 4$ ). Rbāṣā karyā $<{ }^{\overline{\mathrm{E}}}>$ is only occasionally used: it contrasts with $\left.<^{\mathrm{I}}\right\rangle$ for $\bar{i}$ in the last syllable of $\operatorname{Tr} . \mathrm{C}_{1}{ }^{\mathrm{j}} \mathrm{yl}^{\bar{A}} \mathrm{~h}^{\overline{\mathrm{E}}} \mathrm{n}$ beside $\mathrm{C}^{\mathrm{J}} \mathrm{yl}^{\overline{\mathrm{A}}} \mathrm{h}^{\mathrm{I}} \mathrm{n}$ ilāhin, apparently for standard ilähī'divine,' and stands for $i$ in AH $4 h^{\bar{A})} \mathrm{m}^{\overline{\mathrm{E}}} 1^{\mathrm{A}} \mathrm{s}$ h hämila$s$ 'will be pregnant.' Finally, the spellings AH $22 \mathrm{~h}^{\mathrm{I}} \mathrm{m}^{\bar{A}}$ s bima for literary New Persian hama and $\mathrm{AH} 1,13,14 \mathrm{~s}^{\mathrm{I}} \mathrm{x}^{\mathrm{U}} \mathrm{wn}$ sixun for literary New Persian saxun (suxun, suxan) seems to be linguistically relevant and to point here to a pronunciation with $i$ instead of $a$.

Differently from other Syro-Persian texts where $<y>$ at the end of the word also represents $-\bar{a}$ on the model of the Arabic alif maqșūra (e.g. MT 2a, 4a, 6b 'ysy $\bar{T}_{s} \bar{a}$ 'Jesus'), CCM 398

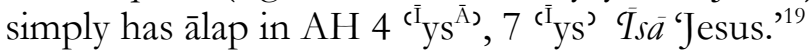

In the two Mardin manuscripts a stylised small Arabic dotless jīm subscribed to $\langle g\rangle$ ( $\underset{\sim}{\sim}$ here transliterated $j)$ is regularly used to differentiate the palatal affricates $j$ and $c$ from velar $g$ (the latter being written $\langle\mathrm{g}>$ or $<\dot{\mathrm{g}}>$ with overdot for plosive pronunciation according to Syriac orthography: $\rightarrow$ or $\checkmark)$. This device, not consistently used in DCA 94 and clearly derived from Islamic manuscripts, ${ }^{20}$ is not found, to the best of our knowledge, in the manuscripts of other Syro-Persian texts published so far, but is known from Arabic Garshuni. ${ }^{21}$ It occurs practically in the totality of the occurrences of $j$ and

19 See Mauro Maggi, "A Syro-Persian version of Matthew 23.29-35," in Scritti in onore di Giovanni M. D'Erme, ed. Michele Bernardini and Natalia L. Tornesello, vol. 1 (Napoli: Università degli studi di Napoli L'Orientale, 2005), 645; Maggi and Orsatti, "Two Syro-Persian hymns," 259; and cf. Adam C. McCollum, "Garshuni as it is: Some observations from reading East and West Syriac manuscripts" (Hugoye: Journal of Syriac studies 17:2 [2014]), 229.

${ }^{20}$ For epigraphic scripts, see Adolf Grohmann, Arabische Paläographie, II. Teil, Das Schriftwesen; die Lapidarschrift (Wien: Böhlaus, 1971), 42-46 \4.

${ }^{21}$ Cf. McCollum, "Garshuni as it is," 230 with n. 35. 
c. Tr. 'jmy' 'ajamàya 'Persian' (loanword in the Syriac title; $\mathrm{C}_{1}$ 'gmy') and jA $\mathbf{b}^{\mathrm{A}}$ r jabbār 'almighty;' AH 2 bjbryl, 12 jbryl (ba) Jibril '(to) Gabriel,' 8 jA $\mathrm{w}^{\bar{A}} \mathrm{~b}$ javāb 'answer,' 9 jÿ ci 'what,' 8, 10 $\mathrm{h}^{\mathrm{A}} \mathrm{mj}^{\mathrm{U}}$ wn hamcun 'thus, like that' (cf. the lectiones faciliores PS $3 \mathrm{CZ}$ hmjwn, $\mathrm{D} \mathrm{h}^{\mathrm{A}} \mathrm{mj}^{\mathrm{U}} \mathrm{wn}$ instead of hmgwn hamginn), $18^{\mathrm{CA}} \mathrm{jb}$ 'ajab '(what a) wonder,' $19 \mathrm{C} \mathrm{w}{ }^{{ }^{A}} \mathrm{jb}^{\mathrm{A}} \mathrm{s}$ väjib-as is fitting' (as against $\left.\mathrm{D} \mathrm{w}{ }^{\mathrm{A}} \mathrm{gb}^{\mathrm{A}} \mathrm{s}\right), \mathrm{PS} 2 \mathrm{C}$ jy, $\mathrm{D} \mathrm{j}^{\mathrm{I}} \mathrm{y} c i$ 'what' $(2 \times)$, and $5 \mathrm{C}$ $j^{A} \mathrm{w}^{\bar{A}} \mathrm{~b}, \mathrm{D} \mathrm{jw}^{\mathrm{A} s} \mathrm{~b}$ javāb 'answer.' Instead, simple $<\mathrm{g}>$ or a modified $\langle\mathrm{g}\rangle$ with one or two strokes in the middle $(\mathbf{A})$ are used for $j$ and $c$ in ZFRN 197 and the two Mingana manuscripts. ${ }^{22}$

The only two occurrences of fricative $\dot{g}$ in the three texts under consideration are simply written $\langle\mathrm{g}\rangle(\boldsymbol{\Delta})$ in $\mathrm{AH} 20$ $\mathrm{g}^{\mathrm{A}} \dot{\mathrm{p}}^{\mathrm{U}} \mathrm{wr} \dot{g} a f \bar{u} r$ 'clement' and $\mathrm{C} \mathrm{g}^{\mathrm{A}} \dot{\mathrm{p}}^{\overline{\mathrm{A}}} \mathrm{r}^{\mathrm{A}} \mathrm{s}, \mathrm{D} \mathrm{g}^{\mathrm{A}} \dot{\mathrm{p}}^{\overline{\mathrm{A}}} \mathrm{r}^{\overline{\mathrm{A}}} \mathrm{s} \dot{\mathrm{g}}$ affär-as 'he is forgiving. ${ }^{23}$ There are no instances of $\langle\mathrm{k}\rangle$ ( ) for $g$ on the model of the Arabo-Persian orthography, a usage which is occasionally found in the Maundy Thursday bymn in Mingana Syr. $520^{24}$ (the single instance of the comparable spelling $<\mathrm{b}>$ (a) for $p$ on the model of the Arabo-Persian orthography in $\mathrm{AH}$ $23 \mathrm{C} \mathrm{b}^{\mathrm{A}} \mathrm{d}^{\bar{I}} \mathrm{yd}^{\overline{\mathrm{A}}} \mathrm{r}, \mathrm{D} \mathrm{b}^{\mathrm{A}} \mathrm{d}^{\overline{1}} \mathrm{yd}^{\overline{\mathrm{A}}} \mathrm{r}$ padidār 'the one who begets' is probably due to the copyist's misunderstanding of his source, see $\left.\int 4\right)$.

Another orthographic characteristic to be observed in CCM 398 and DCA 94 is $\langle\mathrm{p}>$ with overdot ( $\dot{\boldsymbol{s}}$, here transliterated $\dot{\mathrm{p}}$ ) to represent fricative $f$ instead of plosive $p$ as usually in Syriac orthography. This usage, too, can be ascribed

22 See Maggi and Orsatti, “Two Syro-Persian hymns,” 258.

23 Other occurrences of $/ \dot{g} /$ in Syro-Persian texts are to be found in the Matthew excerpt, where it is written $\langle\mathrm{g}\rangle$ with underdot (rukkakā) transliterated $\langle\gamma\rangle$, and in the bilingual (Syriac and New Persian) Psalter and the pharmacological fragments from Turfan, where it is written by means of a modified gāmal transliterated $<\breve{g}>$ : see Maggi, "A Syro-Persian version of Matthew 23.29-35," 642; Maggi and Orsatti, "Two Syro-Persian hymns," 256 n. 28; Nicholas Sims-Williams, "Early New Persian in Syriac script: Two texts from Turfan," (Bulletin of the School of Oriental and African Studies 74:3 [2011]), 354, 363.

24 See Maggi and Orsatti, "Two Syro-Persian hymns," 256, 258. 
to the influence of the Arabo-Persian orthography, in which $f$ is represented by a letter with a point above (ف) at least in the Eastern Arabic scripts as opposed to Maghribi scripts (see below for the similar calque of Arabic $b<\mathrm{z}>$ through $<\mathrm{t}>$ with overdot, $\dot{f}){ }^{25}$ The notation $<\dot{\mathrm{p}}>$ applies to all of the occurrences of $f$ in CCM 398 and DCA 94 ( $f$ does not occur in the short Syro-Persian text of CCM 10, the Trisagion): AH 1 $\mathrm{g}^{\mathrm{U}} \mathrm{wp}^{\mathrm{A}} \mathrm{A}^{\mathrm{s}}$ guftas 'he spoke,' $6 \mathrm{~s}^{\mathrm{A}} \dot{\mathrm{pr}} \mathrm{A}^{\mathrm{A}} \mathrm{s}$ safäraš 'request (to do something)' (cf. standard sifäriš beside sipäriš), $12 \dot{\mathrm{g}}^{\mathrm{U}} \mathrm{wp} \dot{\mathrm{p}}$ guft 'he

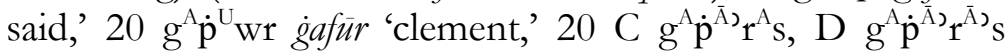
gaffär-as 'is forgiving,' $23 \mathrm{C} \mathrm{g}^{\mathrm{U}} \mathrm{wp}^{\mathrm{A}} \mathrm{A}^{\mathrm{A}} \mathrm{m}, \mathrm{D} \mathrm{g}^{\mathrm{U}} \mathrm{wp} \mathrm{t}^{\mathrm{A}} \mathrm{m}$ guftam 'I said', and PS 1, $4 \dot{\mathrm{g}}^{\mathrm{U}} \mathrm{w} \dot{\mathrm{pt}}^{\mathrm{A} / \overline{\mathrm{A}}} \mathrm{s}$ guftas 'he said'. As opposed to $<\dot{\mathrm{p}}>,<\mathrm{p}>$ without diacritical point $(s)$ represents $p$ in the two Mardin manuscripts: Tr. C p ${ }^{\bar{A}} \dot{\mathrm{k}}, \mathrm{C}_{1} \mathrm{p} \dot{\mathrm{k}} p \bar{a} k$ 'holy;' AH $7 \mathrm{p}^{\mathrm{A}} \mathrm{yd}^{\bar{A}}{ }^{\mathrm{A}} \mathrm{s}$ paydā$s$ 'is conceived' (see $\int 4$ for this transcription and translation).

A further feature certainly due to influence of the Arabic orthography is the regular use of final $<y>$ with two subscript horizontal points $(\overrightarrow{,}$ here transliterated $\ddot{y}$ ) for all of the occurrences of palatal vowels at word end in CCM 398 (no occurrences in CCM 10): AH 3 k̈̈ ki 'that,' 9 jy $c i$ 'what,' 11 $\mathrm{k}^{\mathrm{A}} \mathrm{s} \ddot{\mathrm{y}}$ kas-i ‘'somebody,' 20 k̈̈ ki 'because,' 22 kÿ ki 'whom;' and PS 2 jÿ $c i$ 'what' $(2 \times), 5 \mathrm{k}^{\mathrm{A}} \mathrm{sy}$ kas-e 'somebody' (the texts of Maundy Thursday bymn and PS in the Mingana manuscripts, especially in Mingana Syr. 520, seem to give evidence of the preservation of the majhūl vowels).$^{26}$ In the Matthew excerpt $<y>$ with two subscript horizontal points is occasionally used in non-final position to represent Eastern Persian $\bar{e}$ in the second plural verbal ending -éd after a glide $-y$ - (ي). ${ }^{27}$

In $\mathrm{AH} 1,6 \mathrm{x}^{\mathrm{U}} \mathrm{wd}^{\bar{A}} \overrightarrow{\mathrm{h}} \times$ xudāh 'the Lord,' final $<\dot{\mathrm{h}}>$ with a point above (ं) has quite surely to be interpreted as an actually

${ }^{25}$ Cf. McCollum, "Garshuni as it is," 231.

${ }^{26}$ See Maggi and Orsatti, "Two Syro-Persian hymns," 259.

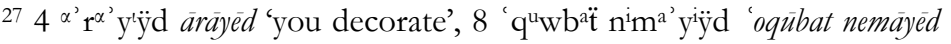
'you (will) punish': see Maggi, “A Syro-Persian version of Matthew 23.2935," 644-646. 
pronounced $-h$. It also occurs in the Baptism bymn $\left(1,10 \mathrm{n}^{\overline{\mathrm{I}}} \mathrm{g}^{\overline{\mathrm{A}}} \mathrm{h}\right.$ nigāh 'gaze,' 4, 8, $12 \mathrm{r}^{\bar{A}} \dot{\mathrm{h}}$, that is, the postposition $\left.-r \bar{a}(b)\right)$, and the Syro-Persian Psalter from Turfan (Iv6 hm ${ }^{\mathrm{A}} \mathrm{h}$ hamah 'all'). ${ }^{28}$

The 'only Arabic' letters, that is, the letters only found in Arabic loanwords in Persian, are mostly carefully transliterated by the corresponding letters, or letters with diacritical point, of the Syriac alphabet:

- Arabic $<\mathrm{h}>=$ Syriac $<\mathrm{h}>(\boldsymbol{w}):$ AH 3, 13, $16(3 \times) \mathrm{h}^{\mathrm{A}} \mathrm{q}^{\mathrm{A}} \mathrm{s}$ Haqq-as 'is (...) God,' $4 \mathrm{~h}^{\overline{\mathrm{A}} \mathrm{s}} \mathrm{m}^{\overline{\mathrm{E}}} \mathrm{l}^{\mathrm{A}} \mathrm{s}$ h hamila-s 'is pregnant,' 19 $\mathrm{t}^{\mathrm{Aa}} \mathrm{sb}^{\mathrm{I}} \mathrm{yh}$ tasbih 'praise,' $21 \mathrm{r}^{\mathrm{Aa}} \mathrm{h}^{\mathrm{I}} \mathrm{ym}$ rahim 'merciful,' 21

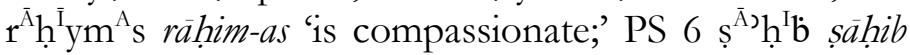
'possessed of;'

- Arabic <s $>=$ Syriac $<s>(s)$ : AH $5 \mathrm{~m}^{\mathrm{U}} \mathrm{wk}^{\mathrm{A}} \mathrm{l}^{\mathrm{I}} \mathrm{y}$ ṣ muxallis 'saviour;' PS $6 \mathrm{~s}^{\bar{A} \mathrm{~s}} \mathrm{~h}^{\mathrm{I}} \mathrm{b}$ șāḥib 'possessed of;'

- Arabic <ț $>$ Syriac <ṭ> (†): AH $17 \mathrm{~b}^{\overline{\mathrm{A}})} \mathrm{t}^{\mathrm{I}} \mathrm{n}$ bātin 'concealed;'

- Arabic $<z>$, a letter having no match in the Syriac alphabet, is rendered by simple $<\mathrm{z}>(\mathbf{9})$ in AH $17 \mathrm{z}^{\bar{A}} \mathrm{~h}^{\mathrm{I}} \mathrm{r}$ $z a \bar{b} i r^{\text {' }}$ manifest', but by $<\mathrm{t}>$ with overdot $(\mathfrak{t})$ in PS 6 CD ${ }^{\mathrm{A}} \mathrm{Z}^{\mathrm{I}} \mathrm{ym}^{\mathrm{A}} \mathrm{s}$ 'azim-as 'is great' (the other manuscripts have simple $<t>$ ) in imitation of the Arabic script, which

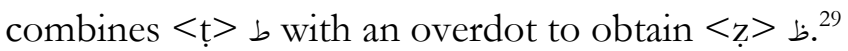

- Arabic $<^{c}>$ is always transliterated by Syriac $<^{c}>(\mathbf{s})$;

${ }^{28}$ Orsatti, "Syro-Persian formulas," 152-154 with n. 31; Sims-Williams, "Early New Persian in Syriac script," 355 with n. 13, 357, 369. For pronunciation, see Fritz Meier, "Aussprachefragen des älteren Neupersisch," 156-159 and Gilbert Lazard, "Remarques sur le fragment judéo-persan de Dandān-Uiliq," in A green leaf: Papers in honour of Professor Jes P. Asmussen (Leiden: Brill, 1988), 207; cf. Maggi, "A Syro-Persian version of Matthew 23.29-35," 648 with nn. 29-31 and George Anton Kiraz, Türrās Mamllā: A grammar of the Syriac language, vol. 1, Orthography (Piscataway: Gorgias Press, 2012), 93 \ 203.

${ }^{29}$ Cf. McCollum, "Garshuni as it is," 231-232. 
- Arabic $<\underline{\mathrm{s}}>=$ Syriac $<\underline{\mathrm{t}}>$ (i.e. $<\mathrm{t}>$ with underdot for fricative pronunciation, $\mathbf{s})$ in PS $4 \mathrm{C} \mathrm{m}^{\mathrm{A}} \underline{\mathrm{t}}$ masal 'parable, D mt mis $l$ 'equal.'

The preposition $b a-/ b i$ - is written $\langle\mathrm{b}\rangle$ attached to the following word, as it generally is in the most ancient AraboPersian orthography and unlike in Judaeo-Persian orthography. It is not vocalised, or vocalised with $\left.<^{\mathrm{I}}\right\rangle$ or $\left.<^{\mathrm{A}}\right\rangle$, apparently without any linguistic reason, and is transcribed here as $b a$ unless it is expressly vocalised with $i$ : AH 2 bjbryl $b a$ Jibril 'to Gabriel,' 4 b $\mathrm{b}^{(\overline{\mathrm{I}} \mathrm{ys}}{ }^{\bar{A})}$ ba $\bar{T}_{s} \bar{a}^{\text {' }}$ with Jesus,' $6 \mathrm{~b}^{\mathrm{I}} \mathrm{m}^{\bar{A})}$ bi $m \bar{a}^{-}$'to

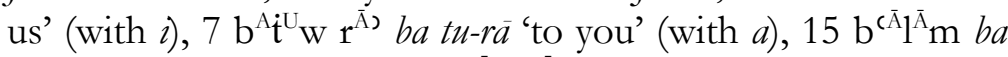
'álam 'into the world,' $19 \mathrm{~b}^{{ }^{\bar{A}}} \mathrm{nr}^{2 \bar{A}} b a \bar{A} n-r \bar{a}$ 'to Him' (on the circumposition $b a \ldots-r \bar{a}$, see $\ 4$ ).

In addition, it may be noted that, of the Arabic orthographic signs, only the tašdīd ( - , marking the doubling of a consonant and here transliterated :) is used once in manuscript ZFRN 197: PS $1 \mathrm{Z} \mathrm{m} \mathrm{m}^{\mathrm{c}} \mathrm{m}: \operatorname{lr}$ for ${ }^{*} \mathrm{~m}^{\mathrm{C}} \mathrm{m}^{\mathrm{r}} \mathrm{r}{ }^{*} M i{ }^{c} m \bar{r}{ }^{6}$ the (Supreme) Architect' (see $\left.\int 4\right) .^{30}$

The iżāfa particle $(-\imath)$ is never written. Moreover, there is one instance of the conjunction $u$ 'and' left unwritten: AH 17 $\mathrm{z}^{\overline{\mathrm{A}} \mathrm{s}} \mathrm{h}^{\mathrm{I}} \mathrm{r} \mathrm{b}^{\overline{\mathrm{A}} \mathrm{s}} \mathrm{t}^{\mathrm{I}} \mathrm{n}$ zähirir u bätin 'manifest and concealed' (see $\int 4$ ).

The following table summarises the peculiarities in the usage, transliteration, and transcription of the Syriac script for writing Persian in mss. $\mathrm{C}, \mathrm{C}_{1}, \mathrm{D}$, and $\mathrm{Z}$, as far as consonants are concerned:

Syriac script

$<\mathrm{b}>$

$<$ b $>$ with overdot

$<\mathrm{g}>$

$<\mathrm{g}>$ with overdot

$<$ g $>$ with subscript jīm

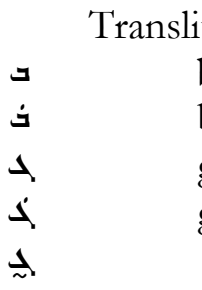

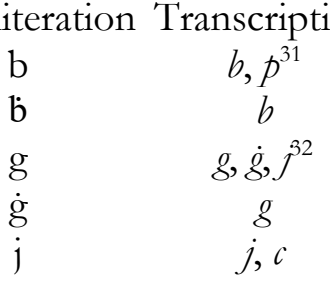

${ }^{30}$ Cf. McCollum, "Garshuni as it is," 233 on tašdīd in Garshuni.

${ }^{31}$ Only in AH $23 \mathrm{~b}^{\mathrm{A}} \mathrm{d}^{\overline{1}} \mathrm{yd}^{\bar{A}}{ }^{\text {' }} \mathrm{r}$ padidār 'the one who begets'.

32 Only in $\mathrm{AH} 19 \mathrm{D} \mathrm{w}^{\prime} \mathrm{Agb}^{\mathrm{A}} \mathrm{S}$ vajïb-as 'is fitting'. 
$<$ g $>$ with a middle

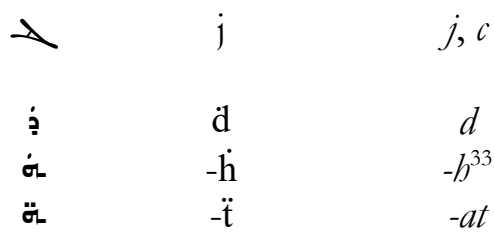

stroke

$<\mathrm{d}>$ with overdot

$<$ h $>$ with overdot

$<$ h $>$ with two dots

a.

$-\ddot{\mathrm{t}}$

$-a t$

above

$<$ z $>$

$<t>$ with overdot

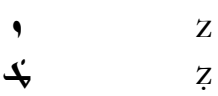

$z(\mathrm{AH})$

(Arabic b)

$<\mathrm{t}>$

$<\mathrm{k}>$

$<\mathrm{k}>$ with underdot

$<\mathrm{k}>$ with overdot

$<\mathrm{p}>$ with overdot

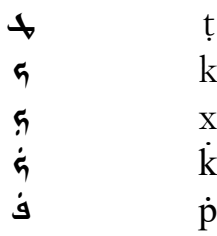

$z$ (PS)

(Arabic ف)

$<\mathrm{t}>$ with overdot

$\dot{a} \quad \dot{\mathrm{t}}$

$z$ (PS)

$\mathrm{k} \quad k, x$

$\mathrm{x} \quad x$

$\mathrm{k} \quad k$

$\dot{\mathrm{p}} \quad f$

$<\mathrm{t}>$ with underdot

$\rightarrow \quad \underline{t}$

$\underline{s}$ (PS)

For vowels, apart from the aforementioned instances of graphic fluctuation (including rbāsā karyā e $<^{\bar{E}}>$ for $i$, i), the usage, transliteration, and transcription of the Syriac letters and vowel points and the Arabic vowel signs in mss. C, $C_{1}, D$, and $\mathrm{Z}$ can be summarised as follows:

Syriac script

ptāḥā

zqāpā

rbāṣā ’arrīkā

hibāṣā

'ṣāṣā cāllịṣā

'ṣāṣā rwị̀̂ā

final yod with two

points below
Transliteration Transcription

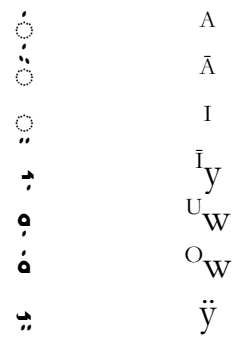

33 Only in AH 1, $6 \mathrm{x}^{\mathrm{U}_{\mathrm{Wd}} \mathrm{A}^{\mathrm{A}} \mathrm{h}}$ xudāh 'Lord'. 
Arabic signs

fatha
Transliteration Transcription

$a$

(AH $2 \times$, PS)

\section{TEXT AND TRANSLATION}

The three texts are given here in facsimile, transliteration, transcription, and translation. ${ }^{34}$ In the critical text, preference is given to the orthographically more informative manuscript readings. Even minor spelling differences are recorded in the apparatus in order to document the orthographic usage. Editorial emendations that diverge, albeit slightly, from the manuscript tradition, are marked by an asterisk (*). Punctuation marks have been normalised using only the single $\operatorname{dot}($.$) and the four dots (\because)$. Differences in interpunction are not recorded in the apparatus unless interpunction is changed in the critical text.

The transcription conventionally adopts the classical pronunciation of vowels, ${ }^{35}$ while, for consonants, it reflects the Arabo-Persian orthography but also accounts for the peculiar manuscript spellings in certain cases. Because the iżäfa is not written, it is conventionally added everywhere in the transcription according to current usage. Extra vowels added for rhyme are enclosed in parentheses ().

\subsection{Trisagion ( $\mathrm{Tr}$.}

Manuscripts: C 244r21-23; C1 8r14-16 (Figs. 1-2).

The Persian version is preceded by Syriac transcriptions of the Trisagion in Latin ("Sanctus Deus") ${ }^{36}$ and its renditions in

${ }^{34}$ Photos courtesy of the Hill Museum \& Manuscript Library, Saint John's University, Minnesota, USA. Published with permission of the Chaldean Cathedral, Mardin, Turkey; the Chaldean Diocese of Alqosh, Iraq; and the Deyrulzafaran Monastery, Mardin, Turkey. All rights reserved.

35 This does not apply to bibliographic references.

36 This actually applies only to manuscript CCM 398, where the Trisagion features as the seventh stanza appended to the first six stanzas of 
Greek, Armenian, and Georgian. There follow Syriac transcriptions of the Turkish, Arabic, and Syriac translations. The wording of the Persian version differs from the one in the polyglot Trisagion in Armenian script in the Yerevan manuscript Matenadaran $7117 .^{37}$

(...) dmttrgm blšn ${ }^{\bar{A})}\left(j m y^{\prime}\right.$.

$\mathrm{p}^{\bar{A}} \dot{\mathrm{k}} \mathrm{x}^{\mathrm{U}} \mathrm{wd}^{\bar{A}} \mathrm{w}^{\bar{A}} \mathrm{n} \cdot \mathrm{j}^{\mathrm{A}} \dot{b}^{\bar{A}} \mathrm{r} \mathrm{x}^{\mathrm{U}} \mathrm{wd}^{\bar{A}} \mathrm{w}^{\bar{A}} \mathrm{n} \cdot \mathrm{n}^{\overline{\mathrm{A}} \mathrm{s}} \mathrm{m}^{\mathrm{I}} \mathrm{rd} \mathrm{wn}^{\bar{A}} \mathrm{~m}^{\overline{\mathrm{I}}} \mathrm{yr}^{\mathrm{A}} \mathrm{d} \cdot \mathrm{wy}^{\mathrm{A}} \dot{\mathrm{k}}$ $\mathrm{x}^{\mathrm{U}} \mathrm{wd}^{\bar{A}} \mathrm{w}^{\bar{A}} \mathrm{n} \cdot{ }^{\overline{\mathrm{T}}} \mathrm{yl}^{\overline{\mathrm{A}}} \mathrm{h}^{\mathrm{I}} \mathrm{n} \mathrm{j}^{\mathrm{A}} \mathrm{b}^{\bar{A}} \mathrm{r} \because$

dmttrgm] dm'trgm $C_{1} . \quad$ blšn $\left.{ }^{\bar{A} \jmath}\right]$ blšn' $C^{\prime}$. 'jmy'] 'gmy' $C_{1} . \quad p^{\bar{A} \dot{k}}$

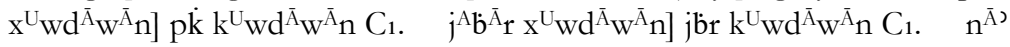

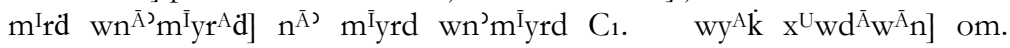

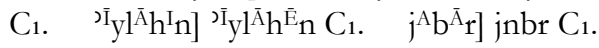

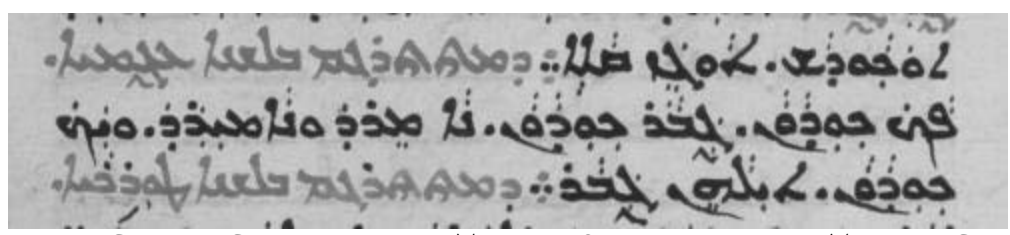

Fig. 1: Chaldean Cathedral, Mardin, Turkey, MS 398, fol. 244r21-23 (Trisagion, C).

the Latin hymn O filii in Syriac transcription. Manuscript CCM 10 has only the first stanza of $O$ filii, followed by Syriac transcriptions of the Trisagion in Greek and other languages, that are qualified as "translated" (mettargam) from Latin. See Takahashi, "Armenian Garshuni," 110; Idem, "The hymn 'O filii' in Syriac transcription" (forthcoming), $\mathbb{S} 2$.

${ }^{37}$ See David N. MacKenzie, "The language of the Medians" (Bulletin of the School of Oriental and African Studies 22 [1959]), 354, where it is transcribed

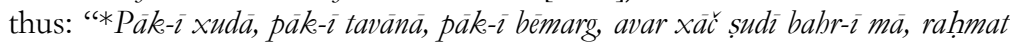
kun "var mä," that is, "Holy God, holy strong, holy immortal, you (who) were crucified for us, have mercy on us.' Another polyglot Trisagion in Armenian script is contained in manuscript Matenadaran 4618, fol. 126: see Andrea Schmidt, "Arménien et syriaque," in Claude Mutafian (ed.), Arménie: la magie de l'écrit (Paris: Somogy, 2007), 345-348. "The text of the part visible on the photograph on p. 345 (the versions of the Trisagion in Greek, Syriac and Georgian, and the first four words of the Persian version) is essentially identical to that in Matenadaran 7117" (Takahashi, "Armenian Garshuni," 101 n. 44). 


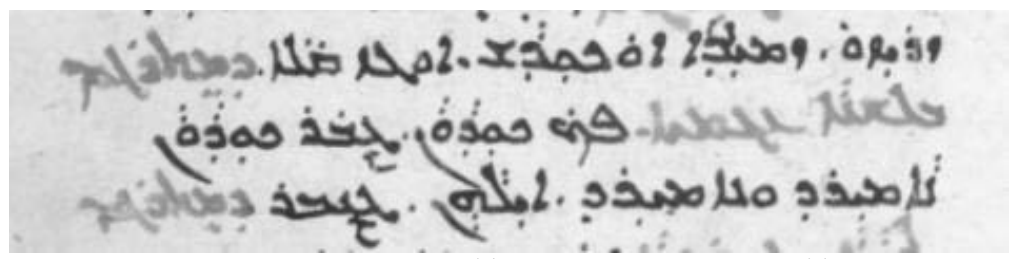

Fig. 2: Chaldean Cathedral, Mardin, Turkey, MS 10, fol. 8r14-16 (Trisagion, $\mathrm{C}_{1}$ ).

\section{[Syriac] (...) d-mettargam b-lešānà 'ajamāàā:}

[Persian] Pāk xudāvan, jabbār xudāvan, namird va namīrad va yak xudāvan, ilāhīn, jabbār.

\section{(...) which is translated into Persian language:}

Holy Lord, almighty Lord, he did not die and will not die and (is) the one Lord, divine, almighty.

\subsection{Annunciation hymn (AH)}

Manuscripts: C 244v4-17; D 30v1-4 (Figs. 3-4). ${ }^{38}$

The Syriac title of this hymn is unclear not only because of the reference to resurrection, ${ }^{39}$ but also because šurāya, besides 'beginning,' is also an East Syriac liturgical term which, however, normally refers to short psalms and not to a text such as this. ${ }^{40}$

The hymn is not to be found in Sebastian P. Brock's anthology of Syriac hymns on Mary, though some passages of it bear some resemblance to passages in the lenghtier anonymous hymn n. 41 translated by him, the Dialogue between Mary and the Angel sometimes attributed to Narsai. ${ }^{41}$ Parallels from this dialogue poem (Mary and the Angel for short) and the

38 Raised numbers in bold in the transliterated text refer to the manuscript lines.

${ }^{39}$ Cf. $\int 3.3$ on the mention of resurrection in the Syriac close appended to the Palm Sunday bymn that follows the Annunciation bymn in manuscripts $\mathrm{C}$ and D.

40 See Michael Sokoloff, A Syriac lexicon (Winona Lake: Eisenbrauns, 2009), 1536 s.v. swry'.

${ }^{41}$ Sebastian P. Brock, Bride of light: Hymns on Mary from the Syriac churches, rev. ed. (Piscataway: Gorgias Press, 2010), esp. 14, 125-132. 
Gospels of Luke and Matthew in the New Revised Standard Version $^{42}$ are given in footnotes to the translation below.

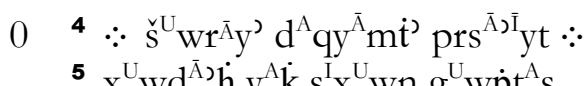
bjbryl $\mathrm{m}^{\mathrm{A}} \mathrm{l}^{\mathrm{A}} \dot{\mathrm{k}}{ }^{\mathrm{U}} \mathrm{wn}^{\mathrm{A}} \mathrm{s}$.

$6 \mathrm{~m}^{\overline{1}} \mathrm{y} \mathrm{d}^{\bar{A}} \mathrm{n}^{\mathrm{A}} \mathrm{m} \dot{\mathrm{k}} \ddot{\mathrm{y}} \mathrm{b}^{\mathrm{A}} \dot{\mathrm{t}}^{\mathrm{U}} \mathrm{wl} \mathrm{h}^{\mathrm{A}} \mathrm{q}^{\mathrm{A}} \mathrm{s}$. $m r y m h^{A} m b^{(\bar{L}} y s^{\bar{A}) 7} h^{\bar{A}} m^{\bar{E}} 1^{A} s$.

$5 \mathrm{~m}^{\mathrm{U}} \mathrm{wk}^{\mathrm{A}} \mathrm{l}^{\overline{\mathrm{T}}} \mathrm{ys}{ }^{(\bar{A}} \mathrm{l}^{\bar{A}} \mathrm{~m}^{\mathrm{U}} \mathrm{wn}^{\overline{\mathrm{A}})} \mathrm{s}$.

$\mathrm{x}^{\mathrm{U}} \mathrm{wd}^{\overline{\mathrm{A}}} \dot{\mathrm{h}} \mathrm{b}^{\mathrm{I}} \mathrm{m}^{\overline{\mathrm{A}}>\mathbf{8}} \mathrm{s}^{\mathrm{A}} \dot{\mathrm{p}} \mathrm{r}^{\mathrm{A}} \mathrm{s}_{\mathrm{s}} \mathrm{k}^{\mathrm{A}} \mathrm{rd}^{\mathrm{A}} \mathrm{s}$.

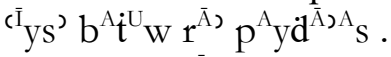
mrym ${ }^{9} j^{A} w^{\bar{A}} b h^{A} m j^{U} w n d^{\bar{A}} d^{A} s$. $y^{\prime}$ jbryl jÿ $s x^{U} w n^{A} s$.

$10{ }^{\mathbf{1 0}} \mathrm{m}^{\mathrm{A}} \dot{\mathrm{g}}^{\mathrm{O}} \mathrm{w} \mathrm{d}^{\mathrm{I}} \mathrm{yg}^{\mathrm{A}} \mathrm{r} \mathrm{h}^{\mathrm{A}} \mathrm{mj} \mathrm{j}^{\mathrm{U}} \mathrm{wn}{ }^{\mathrm{CA}} \mathrm{yb}^{\mathrm{A}} \mathrm{s}$.

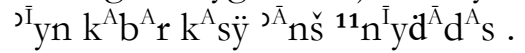
jbryl $\dot{\mathrm{g}}^{\mathrm{U}}$ wṕt $\mathrm{mrym} \mathrm{m}^{\mathrm{A}} \dot{\operatorname{tr}}^{\mathrm{A}} \mathrm{s}$. $\mathrm{q}^{\mathrm{A}} \mathrm{b}^{\mathrm{U}}$ wl ${ }^{12} \mathrm{~b}^{\mathrm{I}} \dot{\mathrm{k}}^{\mathrm{U}}$ wn $\mathrm{s}^{\mathrm{I}} \mathrm{x}^{\mathrm{U}}$ wn $\mathrm{h}^{\mathrm{A}} \mathrm{q}^{\mathrm{A}} \mathrm{s}$. mrym s $\mathrm{x}^{\mathrm{I}} \mathrm{U}^{\mathrm{N}} \mathrm{q}^{\mathrm{A}} \mathrm{b}^{\mathrm{U}} \mathrm{wl} \mathrm{k}^{\mathrm{A}} \mathrm{rd}^{\mathrm{A}} \mathrm{s}$.

$15{ }^{13} \mathrm{~b}^{(\bar{A}} \mathrm{l}^{\bar{A}} \mathrm{~m}\left(\mathrm{y}^{\overline{\mathrm{I}}} \mathrm{s}^{\overline{\mathrm{A}})} *\right)^{\bar{A}} \mathrm{~m}^{\mathrm{A}} \mathrm{d}^{\mathrm{A}} \mathrm{s}$. $\left.h^{A} q^{A} s h^{A} q^{A} s^{C} y^{\bar{I}} s^{\bar{A}}\right) h^{A} q^{A} s$.

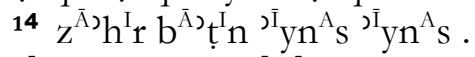
${ }^{(\bar{A}} \dot{j} \dot{b} q^{\mathrm{U}} w_{d r}{ }^{A} \dot{t} w^{3 \bar{A}} y^{\bar{A}} t^{A} s$. ${ }^{15} b^{\partial A} n^{\partial \bar{A}} t^{A a} s b^{\bar{I}} y h w^{\supset \bar{A}_{j}} b^{A} s$.

$20 \dot{k} \ddot{y} h^{A} m g^{A} \dot{p}^{U} w r w h^{A} m{ }^{\mathbf{1 6}} g^{A} \dot{p}^{\bar{A}} r^{A} s$. $w h^{A} m r^{A a} h^{\overline{1}} y m w^{A} m r^{\bar{A}} h^{\overline{1}} y m^{A} s$.

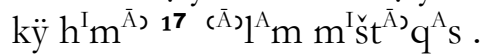

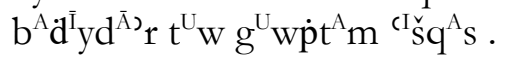

$\left.5 \mathrm{~m}^{\mathrm{U}} \mathrm{wk}^{\mathrm{A}} \mathrm{l}^{\overline{\mathrm{I}}} \mathrm{ys}\right] \mathrm{m}^{\mathrm{U}} \mathrm{wk}^{\mathrm{A}} \mathrm{l}^{\overline{\mathrm{I}}} \mathrm{y} s \underline{\mathrm{C}} \mathrm{C}$ with first ș expunged through a point above and a vertical line below the line to the right. ${ }^{43} \quad 11^{{ }^{\top A}}$ nš] horizontal line over ālap and zqāpā over n. $\left.14 \mathrm{q}^{\mathrm{A}} \mathrm{bw} w^{\mathrm{U}}\right]$ q with ptāhāa miswritten as

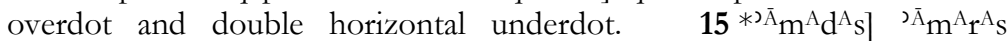

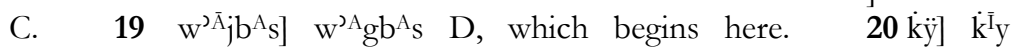

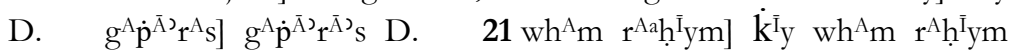

42 The holy Bible: New revised standard version containing the Old and New Testaments (Cambridge: Cambridge University Press, 1989).

43 See Kiraz, Türrās Mamllā, 117 on the supralinear point as an expunction device. 


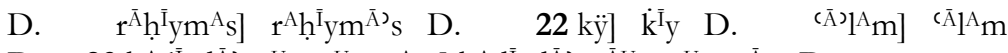

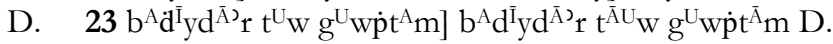

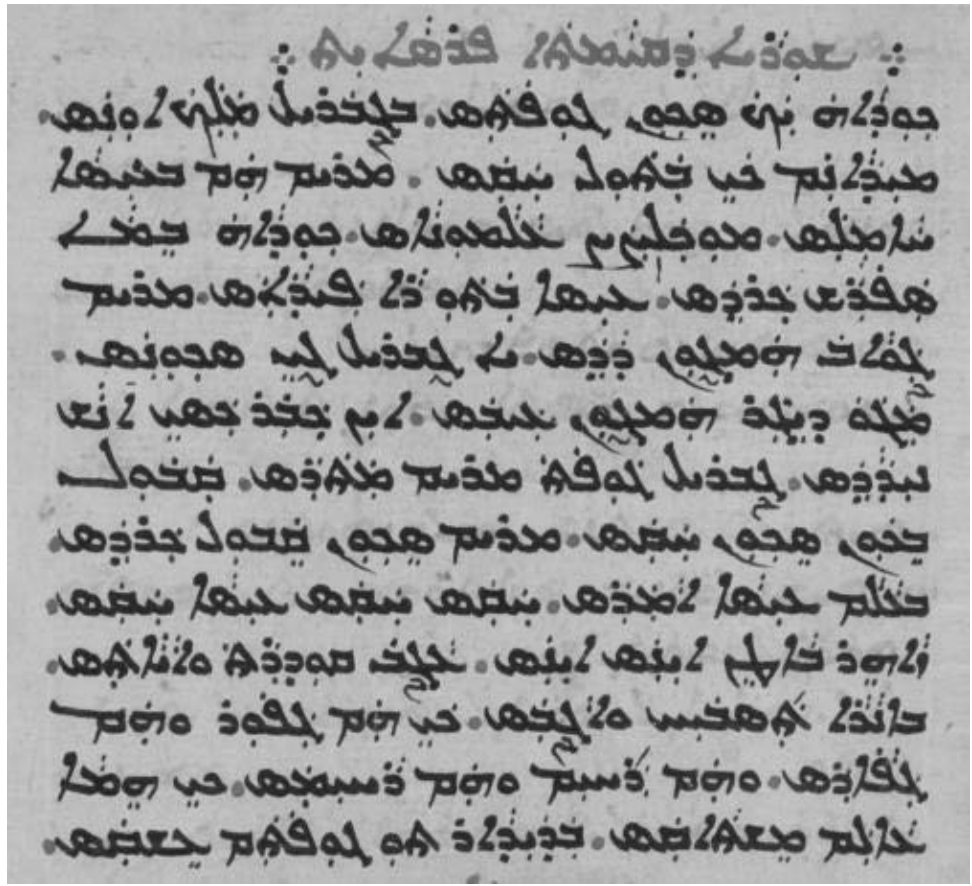

Fig. 3: Chaldean Cathedral, Mardin, Turkey, MS 398, fol. 244v4-17 (Annunciation hymn, C)

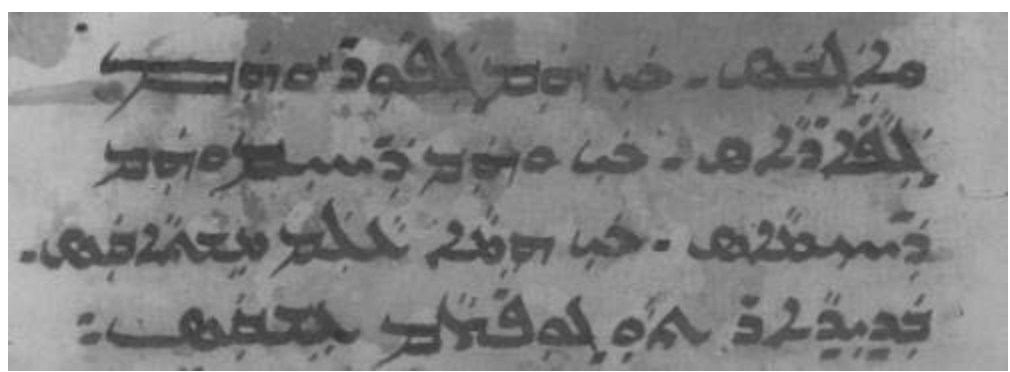

Fig. 4: Chaldean Diocese of Alqosh, Iraq, MS 94, fol. 30v1-4

(Annunciation hymn 19-23, D)

$0 \quad$ [Syriac] Šurāyā da-quāmtā Pārsāàit

[Persian] Xudāh yak sixun guftas

ba Jibrīl, malak-i un(a)s: 
"Mīdānam ki batūl-i Haqq-as, Maryam ham ba 'Īsā ḥāmila-s,

5 muxalliṣ-i ' 'ālam u nās."

"Xudāh bi mā safāraš kardas:

'Īsā ba tu-rā paydā-s."

Maryam javāb hamcūn dādas:

"Yā Jibrīl, ci sixun-as?

10 Magō dīgar hamcūn! 'Ayb-as!

İn xabar, kas-ī ān-š nidādas."

Jibrīl guft: "Maryam, matar(a)s!

Qabūl bikun! Sixun-i Haqq-as."

Maryam sixun qabūl kardas.

15 "Ba 'ālam 'T̄sā *āmadas.

Haqq-as, Haqq-as, 'İsā Haqq-as.

Zāhir u bātịn în-as, īn-as.

'Ajab qudrat u āyāt-as!

Ba Ān-rā tasbīh vājib-as,

20 ki ham gafūr u ham gaffār-as

va ham rahīm u ham rāhim-as,

ki hima 'ālam mištāq-as.

Padīdār-i tu guftam "išq-as."

0 The beginning (?) of resurrection in Persian

The Lord spoke a speech

to Gabriel, angel of intimacy (with God): ${ }^{44}$

"I know that she is a virgin of God,

(but) Mary will also be pregnant with Jesus,

5 the saviour of the world and mankind."

(Gabriel said to Mary:) "The Lord asked me (to announce):

'Jesus is conceived in you'., 45

44 " $[\mathrm{A}]$ nd to Gabriel the angel He [i.e. the Father] gave instructions / to prepare the path before His descent" (Mary and the Angel 6 in Brock, Bride of light, 126).

45 " $[\mathrm{A}]$ greeting did he give her, announcing to her too / concerning her conception" (Mary and the Angel 10 in Brock, Bride of light, 126). "And he came to her and said, 'Greetings, favored one! The Lord is with you ... And 
Mary answered thus:

"O Gabriel, what speech is this? ${ }^{46}$

10 Speak no more like that! It is a fault!

This news, nobody (ever) gave it."

Gabriel said: "Fear not, Mary!

Accept! It is the word of the Truthful one." 48

Mary accepted the speech. ${ }^{49}$

15 (Gabriel said:) "Jesus has * come into the world. ${ }^{50}$

He is God, is God, Jesus is God.

Manifest and concealed is this, is this.

What a power, what signs!

Praise to Him is fitting,

20 who is both clement and forgiving

and is both merciful and compassionate,

whom all the world is longing for. ${ }^{51}$

I have announced (that) the one who begets in you is love." 52

now, you will conceive in your womb and bear a son, and you will name him Jesus" " $(\mathrm{Lk}$ 1.28, 31); "the child conceived in her is from the Holy Spirit" (Mt 1.20).

46 "MARY: And what is this that you utter?" (Mary and the Angel 12 in Brock, Bride of light, 127).

47 "ANGEL: O blessed of women, ... have no fear" (Mary and the Angel 13 in Brock, Bride of light, 127).

48 "ANGEL: ... it is from the True One that I have been sent" (Mary and the Angel 19 in Brock, Bride of light, 128).

${ }^{49}$ Cf. Lk 1.48 ("for he has looked with favor on the lowliness of his servant. / Surely, from now on all generations will call me blessed").

50 "ANGEL: ... He is come and is residing within you" (Mary and the Angel 45 in Brock, Bride of light, 131).

51 "ANGEL: Height and depth shall hold Him in honour, / angels and human kind shall give Him praise" (Mary and the Angel 49 in Brock, Bride of light, 131).

52 "ANGEL: From the Father was I sent / to bring you this message, for His love has compelled Him / so that His Son should reside in your womb" (Mary and the Angel 35 in Brock, Bride of light, 129). Cf. Lk 1.35 ("The angel said to her, "The Holy Spirit will come upon you, and the power of the Most High will overshadow you; therefore the child to be born [note: Other ancient authorities add of you ] will be holy; he will be called Son of God." "). 


\subsection{Palm Sunday hymn (PS)}

Manuscripts: A 10r7-11; B 90v13-91r2; C 244v18-22; D 30v511; Z 99r1-5 (Figs. 5-7). ${ }^{53}$

This short and rather enigmatic hymn seems to refer to the signs of the end of the age revealed by Jesus and his future coming, to the image of Christ seated on the throne of God at the right hand of the Father, and to his power. ${ }^{54}$ It is preceded by the Maundy Thursday bymn in the West Syriac manuscripts A, $\mathrm{B}$, and Z, and by the Annunciation bymn in the East Syriac manuscripts $\mathrm{C}$ and $\mathrm{D}$. The headings sugita 'a type of hymn or dialogue poem' in A, B, and Z, and 'unitā 'antiphonal response; refrain, hymn' in $\mathrm{C}$ and $\mathrm{D}$ seem to be used here as generic terms for 'hymn. ${ }^{55}$ The fact that, in $\mathrm{C}$, the hymn follows the Annunciation bymn and is provided with a different Syriac ending mentioning "resurrection" (qyämtā, as in the Syriac title of the Annunciation bymn) suggests an adaptation to specific liturgical exigencies. ${ }^{56}$

$0 \quad \because$ swgyt $^{\prime} \because$

$1 *_{\mathrm{m}} \mathrm{m}^{\prime} \mathrm{r} \dot{\mathrm{g}}^{\mathrm{U}} \mathrm{wp}_{\mathrm{p}}^{\mathrm{A}} \mathrm{s}$.

$\left.2 j \ddot{y}{ }^{\bar{A}} y^{\bar{A}}\right)_{\mathfrak{t}} w j \ddot{y} q^{U} w d r^{A} t^{A} s$.

$3 \mathrm{p}^{\mathrm{I}} \mathrm{s}^{\mathrm{A}} \mathrm{r}$ hmgwn $n^{\mathrm{I}} \mathrm{s}^{\bar{A}} \mathrm{st}^{\mathrm{A}} \mathrm{s}$.

$4 \mathrm{~h}^{\mathrm{a}} \mathrm{n} *^{\mathrm{N}} \mathrm{m}^{\mathrm{r}} \mathrm{rd} \dot{\mathrm{g}}^{\mathrm{U}} \mathrm{w} \dot{\mathrm{p}} \mathrm{t}^{\mathrm{A}} \mathrm{s}$.

$5 \quad \mathrm{k}^{\mathrm{A}} \mathrm{sy} j^{\mathrm{A}} \mathrm{w}^{\bar{A}} \mathrm{~b} \mathrm{n}^{\overline{\mathrm{A}})} \mathrm{d}^{\bar{A}} \mathrm{~d}^{\mathrm{A}} \mathrm{s}$.

$6 s^{\bar{A}} h^{\mathrm{I}} \dot{b} q^{\mathrm{U}} \mathrm{wdr}^{\mathrm{A}} \dot{\mathrm{t}}{ }^{c \overline{\mathrm{A}}} \mathrm{z}^{\overline{\mathrm{I}}} \mathrm{ym}^{\mathrm{A}} \mathrm{s} \because$

7 'wš'n' brwm'

8 'wšc $n^{\prime} b^{C} w m q$ '.

9 'wš' $n$ ' lbrh ddwyd.

10 bryk d't' bšmh .

CD šwbḥ ${ }^{\top} 1^{\bar{A}} \mathrm{~m}^{\bar{A}} \mathrm{rn}$. šwbḥ ${ }^{\prime} l k$ brh $d^{\mathrm{D}} \mathrm{l}^{\overline{\mathrm{A}}} \mathrm{h}^{\overline{\mathrm{A}} \mathrm{s}}$.

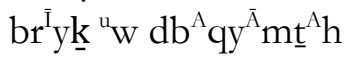
$h^{a} d y^{a} n \because$

11 dmry' wt ${ }^{\mathrm{u}} w \underline{b} \mathrm{n}^{\prime} \underline{t}^{\prime} \because$

${ }^{53}$ See n. 6 for the first publication of manuscripts AB.

${ }^{54}$ Cf. Maggi and Orsatti, "Two Syro-Persian hymns," 251.

${ }^{55}$ Cf. Sokoloff, A Syriac lexicon, 976 s.v. swgyt', 1082 s.v. 'wnyt'.

56 Despite this possibility, we keep the conventional title Palm Sunday bymn for the sake of easy reference. 
0 swgyt'] 'wnyt' C. $\left.\quad 1 *^{*} \mathrm{~m}^{\text {' }} \mathrm{m}^{\mathrm{r}} \mathrm{r}\right] \quad \mathrm{m}^{\mathrm{c}} \mathrm{mlr} \quad \mathrm{AB}, \mathrm{m}^{\mathrm{c}} \mathrm{m}: \mathrm{lr} \quad \mathrm{Z}, \mathrm{m}^{\mathrm{CA}} \mathrm{l}^{\mathrm{I}} \mathrm{ml}^{\mathrm{A}} \mathrm{r}$ CD. $\left.\quad \dot{g}^{\mathrm{U}} \dot{w p}^{\mathrm{A}} \mathrm{s}\right] \dot{\mathrm{g}}^{\mathrm{U}} \mathrm{wp}^{\mathrm{p}^{\mathrm{A}}} \mathrm{s} \mathrm{D}$, gwpts A (with deleted dot over g) ${ }^{57} \mathrm{~B}$, giwpts

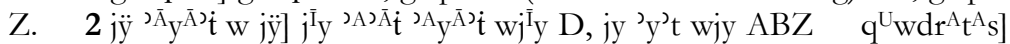

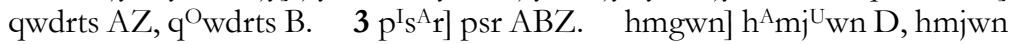
CZ. $\left.\quad n^{I} \check{s}^{-\bar{A}} s t^{A} s\right] n^{I} \check{s}^{A} t^{A} s D$, nšsts $A B Z$ (a suprascript dot over final $-\mathrm{s}$ in B). $\left.\quad 4 h^{a} n\right]$ h ${ }^{\mathrm{u}} \mathrm{n} Z$ (with sukūn over $-\mathrm{n}$ in $\mathrm{ABZ}$ ), $\mathrm{y}^{\mathrm{A}} \dot{\mathrm{k}} \mathrm{C}, \mathrm{y}^{\overline{\mathrm{A}}} \dot{\mathrm{k}} \mathrm{D} . \quad{ }^{*} \mathrm{mrd}$ ] $\mathrm{m}^{\mathrm{\prime}} \mathrm{dr} \mathrm{ABZ}, \mathrm{m}^{\mathrm{A}} \underline{\mathrm{tl}} \mathrm{C}, \mathrm{m}^{\mathrm{I}} \underline{\mathrm{t} l} \mathrm{D} . \quad \dot{\mathrm{g}}^{\mathrm{U}} \mathrm{wp}^{\mathrm{A}} \mathrm{s}^{\mathrm{s}}$ ] gwpts $\left.\mathrm{ABZ} . \quad 5 \mathrm{k}^{\mathrm{A}} \mathrm{s} \ddot{\mathrm{y}}\right] \mathrm{k}^{\mathrm{A}} \mathrm{s}^{\overline{\mathrm{I}}} \mathrm{y} \mathrm{D}, \mathrm{ksy}$ ABZ. $\left.\left.\quad j^{A} w^{\bar{A}} b\right] j w^{\bar{A}} b \mathrm{~b}, g w^{\prime} b A B, j w^{\prime} b Z . \quad n^{\bar{A}} d^{\bar{A}} d^{A} s\right] n^{\bar{A}} d^{\bar{A}} d^{A} s C, n^{\prime} d d^{\prime} s$

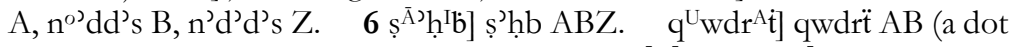

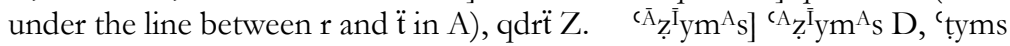

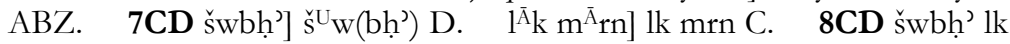
brh] D. $\left.\quad d^{{ }^{A}} l^{\bar{A}} h^{\bar{A}}\right] d^{\prime} l h^{\prime}$ C. $\quad 9$ ddwyd] ddwwyd Z. 9CD bri $\left.{ }^{\bar{I}} \underline{k}^{\mathrm{u}} w\right]$ bryw

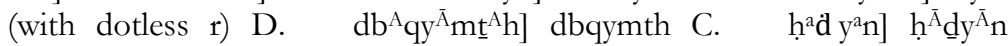
D. $\left.11 w t^{\mathrm{u}} w \underline{b}\right]$ wtwb BZ. $\left.\mathrm{n}^{\prime} \underline{t}^{\prime}\right] \mathrm{n}^{\prime} \mathrm{t}^{\prime} \mathrm{AB}$.

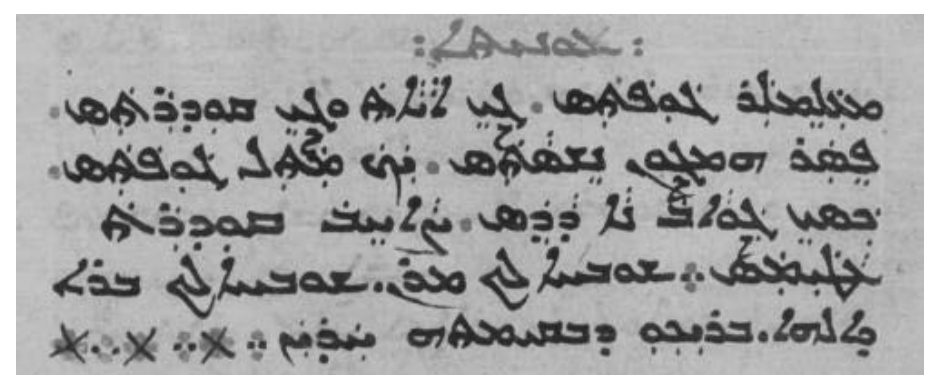

Fig. 5: Chaldean Cathedral, Mardin, Iraq MS 398, fol. 244v18-22 (Palm Sunday hymn, C)

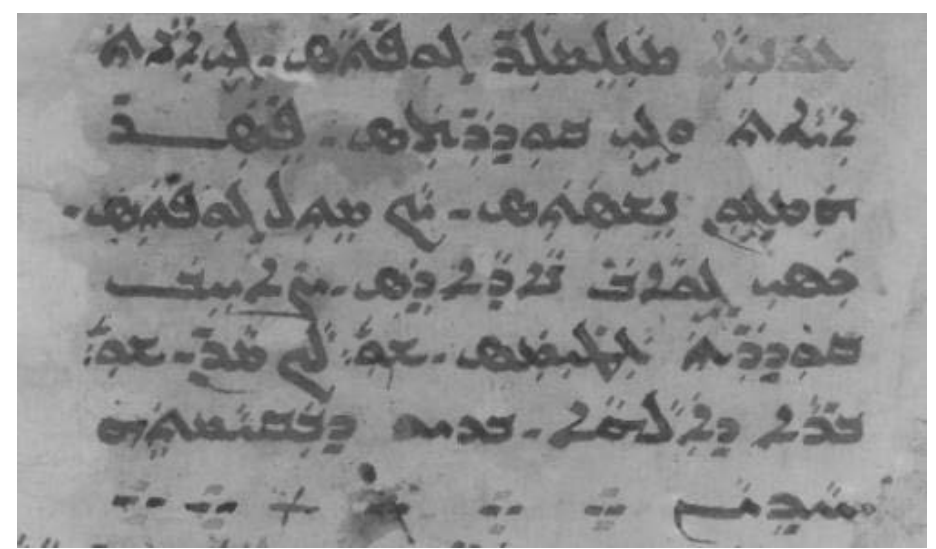

Fig. 6: Chaldean Diocese of Alqosh, Iraq, MS 94, fol. 30v5-11 (Palm Sunday hymn, D).

${ }^{57}$ Read [[w]]gwpts with a query in Maggi and Orsatti, "Two SyroPersian hymns," 271. 


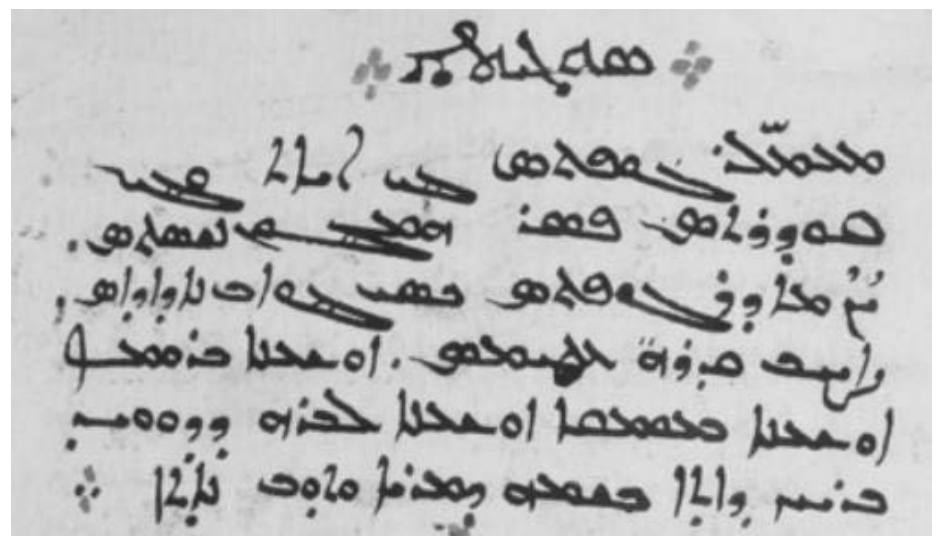

Fig. 7: Deyrulzafaran Monastery, Mardin, Turkey, MS 197, fol. 99r1-5

(Palm Sunday hymn, Z).

$0 \quad$ [Syriac] Sugitā

$1 \quad$ Persian] *Micmār guftas

2 ci āyāt u ci qudrat-as:

3 Pisar hamgūn nišastas.

4 Hān *Mard guftas.

5 Kas-ē javāb nādādas

6 Șāḥib-i qudrat-i 'aẓìm-as.

7 [Syriac] 'Oša'nā b-rāwmā!

8 'Oša'nā b-'umqā!

9 'Oša'nā l-brēh d-Dāwid!

10 Brik d-'etā ba-šmēh

11 d-māryā w-tub nētē!

0 Hymn

1 The (Supreme) Architect (i.e. Jesus) said

2 what the signs and what (his) power are:

3 the Son is seated in the same way (as the Father).

4 The Man (i.e. Jesus) said that.

5 Nobody gave an answer.

6 He has a great power.

CD Šubḥā lāk, māran! Šubhā lāk, brēh d-'Alāhā! Brik-u d-ba-qyāmtēh ḥdayn! 
7 Hosanna in the height!

8 Hosanna in the depth!

9 Hosanna to the son of David!

10 Blessed is the one who came in the name

11 of the Lord and will come again!
CD Praise (be) to you, our Lord! Praise (be) to you, son of God! Blessed is he in whose resurrection we rejoiced!

\section{COMMENTARY}

Tr. $\mathrm{x}^{\mathrm{U}} \mathrm{wd}^{\overline{\mathrm{A}}} \mathrm{w}^{\overline{\mathrm{A}}} \mathrm{n}$ xudāvan 'Lord' (3x) for standard xudāvand (< *bua-tāuant- $)^{58}$ is presumably a spoken form with loss of final $-d$ in the coda of a syllable closed by two consonants. This phenomenon, also attested elsewhere in Syro-persian (MT 2d kwšn kušan 'they will kill'), ${ }^{59}$ is well-known in the contemporary language, where the third plural ending -and and the third plural present and of budan as copula or auxiliary are pronounced -an, an. Less likely is the survival in this text of the Manichaean Middle Persian and Parthian word xwd'wn xwadäwan 'lord' (< *bua-täuan-). ${ }^{60}$

Tr. $\mathrm{n}^{\bar{A})} \mathrm{m}^{\mathrm{I}}$ rd namird 'he did not die' represents a dialectal realisation of classical $u$ as $i$. See also the vocalisation of AH 22 $\mathrm{m}^{\mathrm{I}} \mathrm{s}^{\overline{\mathrm{A}}}{ }^{\mathrm{q}} \mathrm{q}$ mištāq 'longing' for Arabic muśtāq and $1 \mathrm{~s}^{\mathrm{I}} \mathrm{x}^{\mathrm{U}} \mathrm{wn}$ sixun 'speech' for Classical saxun (suxun, suxan). This is a widespread dialectal phenomenon also attested in the Syro-Persian Baptism bymn $2{ }^{\mathrm{I}} \mathrm{stw}^{\bar{A}} \mathrm{r}^{\mathrm{r}}$ ist (a) vār for standard ustuvār 'firm, strong. ${ }^{, 11}$

Tr. ' ${ }^{\bar{I}} \mathrm{yl}^{\bar{A}} \mathrm{~h}^{\mathrm{I}} \mathrm{n} \mathrm{j}^{\mathrm{A}} \mathrm{b}^{\mathrm{A}} \mathrm{r}$ ilähin, jabbār 'divine, almighty.' At the end of the Trisagion one expects the invocation 'have mercy on us,' which actually occurs in the Persian Trisagion in Armenian

${ }^{58}$ Moḥammad Hasandust, Farbang-e rišeséenāxti-ye zabān-e Fārsi (Tehrān: Farhangestān-e Zabān va Adab-e Fārsi, 1393/2014), vol. 2, 1109.

${ }^{59}$ Maggi and Orsatti, "Two Syro-Persian hymns," 278.

${ }^{60}$ Desmond Durkin-Meisterernst, Dictionary of Manichaean Middle Persian and Parthian (Turnhout: Brepols, 2004), 366; Hasandust, Farhang-e rišesenenaxxtiye zabān-e Färsi, vol. 2, 1109.

${ }^{61}$ See Orsatti, "Syro-Persian formulas," 152, 164 with notes 90-95. 
script ${ }^{62}$ as well as, first of all, in the Syriac version (but also in the Latin, Greek, Turkish, Arabic, and presumably Armenian ones) ${ }^{63}$ in the Mardin manuscripts under consideration: C $244 \mathrm{v} 3=\mathrm{C}_{1} 8 \mathrm{r} 22$ 'trḥm $\left(\mathrm{C}_{1}\right.$ trḥm$)$ 'lyn etraḥham 'al-ayn 'have mercy on us! ${ }^{64}$ The two last words in the Syro-Persian version, however, can hadly be interpreted other than the adjectives ilähin 'divine' (remarkably with the material suffix -in instead of the more generic -i of its standard counterpart ilähi, possibly on christological grounds) and jabbār 'almighty', both qualifying the preceding xudàvan 'Lord.'

AH $3 \mathrm{~b}^{\mathrm{A}} \mathrm{t}^{\mathrm{U}} \mathrm{wl} \mathrm{h}^{\mathrm{A}} \mathrm{q}^{\mathrm{A}} \mathrm{s}$ batūl-i Haqq-as 'she is the virgin of God.' Mary is styled "virgin of the Lord" already in the apocryphal Protoevangelium Jacobi (probably from the late second century), which was especially popular in eastern Christianity and now survives in Greek and several eastern versions including Syriac,

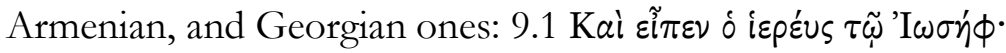

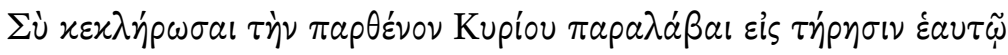
'The priest said to Joseph, "You have been chosen to take the Lord's virgin into your safekeeping.",65 Alternatively, the end of the verse can be read and translated batül-i haqq-as 'she is a true virgin.'

AH $6 \mathrm{~s}^{\mathrm{A}} \dot{\mathrm{p}} \mathrm{r}^{\mathrm{A}} \mathrm{s}$ safäraš 'request (to do something).' See $\int 2$ for the transcription with $-f$ - rather than $-p$ - (cf. standard sifäriš/sipārišs).

62 See n. 37.

63 See Takahashi, "Armenian Garshuni," 99-100 with n. 41 for Armenian, Arabic, and Turkish; and Idem, "The hymn 'O filii' in Syriac transcription" (forthcoming), \$\$ 1-2, 4 for Latin.

64 The Georgian version poses problems: see Adam C. McCollum, "Syro-Georgian Trisagion," at http://hmmlorientalia.wordpress.com/ 2013/10/24/syro-georgian-trisagion.

${ }^{65}$ Émile De Strycker, La forme la plus ancienne du Protévangile de Jacques: Recherches sur le Papyrus Bodmer 5, avec une édition critique du texte grec et une traduction annotée (Bruxelles: Société des Bollandistes, 1961), 106; Bart D. Ehrman and Zlatko Pleše, The apocryphal gospels: Texts and translations (Oxford: Oxford University Press, 2011), 31, 50-51. 


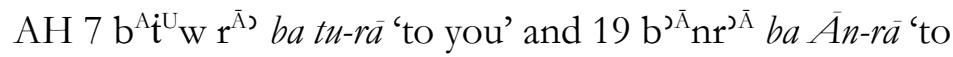
Him.' A circumposition ba ...-rā is attested in literary Early New Persian texts with various meanings: indirect object, direction, purpose. ${ }^{66}$ This form was probably much more widespread in non-literary New Persian. An Early Judaeo-Persian example of directional $b \bar{e} \ldots-r \bar{a}$ is to be found in Argument D4 by pyš

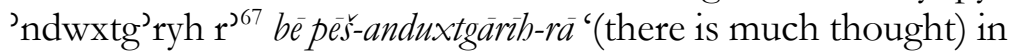
order to accumulate in advance.'

AH $7 \mathrm{p}^{\mathrm{A}} \mathrm{yd}^{\overline{\mathrm{A}}} \mathrm{A}$ s paydā-s '(Jesus) is conceived,' is transcribed with the usual elision, on account of the rhyme, rather than payda as as the spelling suggests. The intransitive verbal periphrasis payda büdan 'to be born, conceived' is not recorded in the standard dictionaries, but is nearly synonymous with paydà àmadan, paydà šodan 'to come into existence, be created; to be born' and parallels the New Persian transitive verbal periphrases paydā àvardan, paydà kardan 'to bring into existence, create; to bear, give birth to' (cf. paydäiš 'coming into being, birth, genesis, etc.'). ${ }^{68}$

${ }^{66}$ See Gilbert Lazard, La langue des plus anciens monuments de la prose persane (Paris: Klincksieck, 1963), 369 \542.

${ }^{67}$ See David N. MacKenzie, "An Early Jewish-Persian argument" (Bulletin of the School of Oriental and African Studies 31:2 [1968]), 258. No examples of $p a(d) / b e$...-rā are offered by Ludwig Paul, "Early JudaeoPersian in a historical perspective: The case of the prepositions be, $u, p a(d)$, and the suffix rä," in Persian origins: Early Judaeo-Persian and the emergence of New Persian: Collected papers of the symposium, Göttingen 1999, ed. Ludwig Paul (Wiesbaden: Harrassowitz, 2003) or Idem, A grammar of Early Judaeo-Persian, $150 \int 184$.

${ }^{68}$ See Ela Filippone, "The Mazdean notions of creation and birth: Some reflexes in the Iranian languages," in Religious themes and texts of preIslamic Iran and Central Asia: Studies in honour of Professor Gherardo Gnoli on the occasion of his 65th birthday on 6th December 2002, ed. Carlo G. Cereti, Mauro Maggi, and Elio Provasi (Wiesbaden: Ludwig Reichert, 2003), 91-92, 98101 and Eadem, "Bearing a child' in Iranian," in One for the earth: Prof. Dr. Y. Mahyar Nawabi memorial volume, ed. Mahmoud Jaafari-Dehaghi (Tehran: Centre for the Great Islamic Encyclopaedia, 2008), 58-59 with reference to the dictionaries by 'Ali Akbar Dehxodā, Logatnāme, ed. Mohammad Mo'in and Ja'far Šahidi (Tehrān: Dānešgāh-e Tehrān, 1324-1359/1946-1981), s.vv. paydà šudan, paydā kardan, paydāyiš and Mohammad Mo in, Farhang-e 
AH 8, $10 \mathrm{~h}^{\mathrm{A}} \mathrm{mj}^{\mathrm{U}}$ wn hamcün can only be taken as an adverb meaning 'thus, like that,' given the contexts where it occurs, although bamcin is chiefly a preposition meaning 'like, as' in the literary language according to the standard dictionaries. ${ }^{69}$ The use of hamcün as an adverb meaning 'thus, like that' is presumably peculiar to the spoken language and recalls modern, mainly spoken forms such as hamci in sentences like cerā hamci negäh-am mikoni? "why do you look at me like that?"70 On PS 3 hmgwn hamgün, see below.

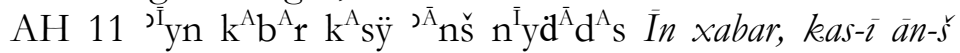
nidādas 'This news, nobody (ever) gave it.' In this clause, the direct object (here without -rāa: In xabar) is in thematic position before the subject (kas-l) and is represented, in the rheme, by the pronoun an 'it' with redundant personal suffix $-s$. This construction can be regarded as peculiar to the spoken language. ${ }^{71}$

AH $11 \mathrm{n}^{\bar{I}} \mathrm{yd}^{\bar{A}} \mathrm{~d}^{\mathrm{A}} \mathrm{s}$ nidādas. A negative verbal prefix $n \bar{\imath}(n \bar{e})$ is not attested in the earliest New Persian texts in Arabic script, ${ }^{72}$ so that $\mathrm{n}^{\overline{\mathrm{I}}} \mathrm{y}$ - is unlikely to represent $n \bar{\imath}$ (the text gives no evidence of the preservation of majhūl $\vec{e}$ ). However, given the fluctuation in the spelling of the palatal vowels in this text,

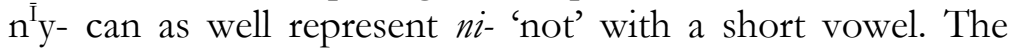

Fārsi-ye motavasset, 7th ed. (Tehrān: Amir Kabir, 1364/1985), vol. 1, 882-884 s.vv. paydà àmadan, paydā àvardan, paydā šudan, paydā kardan, paydāyiš. See also Hasan Anvari, Farhang-e bozorg-e Soxan (Tehrān: Entešārāt-e Soxan, 1381/2002), vol. 2, 1486-1488 s.vv. paydā àmadan, paydā āvardan, paydā šudan, paydā kardan, paydāyis.

${ }^{69}$ Dehxodā, Loğatnāme, s.v. hamcūn: "hamcu, mānand-i, cūn, naẓìr-i;" Anvari, Farhang-e bozorg, vol. 8, 8389 s.v. hamcūn: "mānand-i, misl-i."

${ }^{70}$ See Anvari, Farhang-e bozorg, vol. 8, 8389 s.v. hamcī.

${ }^{71}$ For the syntax of this kind of clauses, see Gilbert Lazard, Grammaire du persan contemporain, nouvelle éd. avec la collaboration de Yann Richard, Rokhsareh Hechmati et Pollet Samvelian (Téhéran: Institut français de recherche en Iran, 2006), 168 \172, 176 \$175, 196 \$ 193.4); and Ju. A. Rubinčik, Grammatika sovremennogo persidskogo literaturnogo jasyka (Moskva: Vostočnaja literatura, 2001), 402-404. Similar constructions are also attested in Early New Persian texts: see Lazard, La langue des plus anciens monuments, 260 \325.c.

72 Cf. Lazard, La langue des plus anciens monuments, 440-441 S 727. 
negative verbal prefix is commonly spelled ny, written separately from the verb and to be interpreted as $n a^{73}$ or $n i{ }^{74}$ in New Persian texts in Manichaean script. The spelling ny is also very frequent in the Early Judaeo-Persian Argument. ${ }^{7}$

AH $17 \mathrm{z}^{\overline{\mathrm{A}} \mathrm{s}} \mathrm{h}^{\mathrm{I}} \mathrm{r}^{\overline{\mathrm{A}} \mathrm{s}} \mathrm{t}_{\mathrm{I}}^{\mathrm{n}} \mathrm{n}$ zăbir u bātin 'manifest and concealed.' The conjunction $u$ 'and,' consisting of a short unstressed vowel, is left unwritten here as it occasionally is in Early New Persian texts in Arabic script. ${ }^{76}$ Omission of the conjunction in writing is found in the ancient fragmentary manuscript of 'Unșurî's poem Vàmiq va 'Ażrā, datable to the eleventh or twelfth century, where it has been duly supplemented by the editors of the text. $^{77}$ Among non-literary manuscripts, the conjunction is not written within a nominal phrase and has been supplemented by the editor 51 times in the Marriage contract from Bāmiyān dated 470/1078, ${ }^{78}$ whereas it is regularly recorded only eight times, all at the beginning of a clause. ${ }^{79}$ As for New Persian texts in other scripts, an instance of unwritten coordinating conjunction is to be found in the qașida in

${ }^{73}$ François de Blois, "Glossary to the New Persian texts in Manichaean script," in Dictionary of Manichaean texts, vol. 2, Texts from Iraq and Iran (texts in Syriac, Arabic, Persian and Zoroastrian Middle Persian), ed. François de Blois and Nicholas Sims-Williams, compiled by François de Blois, Erica C. D. Hunter, and Dieter Taillieu (Turnhout: Brepols, 2006), 109.

${ }^{74}$ Elio Provasi, "New Persian texts in Manichaean script from Turfan," in The Persian language in history, ed. Mauro Maggi and Paola Orsatti (Wiesbaden: Reichert, 2011), 142, 166.

75 MacKenzie, "An Early Jewish-Persian argument," 249-269; and Idem, "An index to 'An Early Jewish-Persian argument'," in The Persian language in history, ed. Mauro Maggi and Paola Orsatti (Wiesbaden: Ludwig Reichert, 2011), 243.

${ }^{76}$ For omission of the conjunction in writing compound numerals (e.g. cibil (u) yak säl 'forty-one years'), see Lazard, La langue des plus anciens monuments, 217 \ 204.

77 Thomas Hägg and Bo Utas, The Virgin and her Lover: Fragments of an ancient Greek novel and a Persian epic poem (Leiden: Brill, 2003), 79.

78 See Gianroberto Scarcia, “A preliminary report on a Persian legal document of 470-1078 found at Bāmiyān" (East and West 14:1-2 [1963]), 73-81; Idem, "An edition of the Persian legal document from Bāmiyān" (East and West 16:3-4 [1966]), 290-295.

${ }^{79}$ Lines 24, 25, 27, $28(2 \times), 29,31(2 \times)$. 
Manichaean script M 786, 1. 22 (verse 9) k’pwr brg '[..](w)rd käfür u barg-i mürd 'camphor and myrtle-leaves' ${ }^{80}$

AH $19 \mathrm{~b}^{\partial \bar{A}} \mathrm{nr}^{2 \overline{\mathrm{A}}}$ ba $\bar{A} n-r \bar{a}$ ' to Him.' On the circumposition ba ...-rāa, see above on $\mathrm{AH} 7 \mathrm{~b}^{\mathrm{A}} \mathrm{t}^{\mathrm{U}} \mathrm{w} \mathrm{r}^{\overline{\mathrm{A}} \text { ) }}$ ba tu-rā' 'to you.' Oddly, $\bar{a} n$ refers here to God. Alternatively, one could translate lines $19-22$ as 'For this (reason) (ba ān-rāa) praise is fitting, because $(k i)$ He is both clement and forgiving and is both merciful and compassionate, $(\mathrm{He})$ whom $(k i)$ all the world is longing for'.

AH $22 \mathrm{~h}^{\mathrm{I}} \mathrm{m}^{\mathrm{A}} \mathrm{s}$ bima 'all.' Though New Persian hama goes back to Middle Persian bamäg with a long vowel in the second syllable, the final ālap vocalised with $<^{\bar{A}}>$ in $h^{\mathrm{I}} \mathrm{m}^{\bar{A}}$ ) is unlikely to represent long $\bar{a}$ (see $\int 2$ for the graphic fluctuation $<^{\mathrm{A}}>\sim$ $<^{\bar{A}}>$ ). The word is likewise usually written $\mathrm{hm}^{\prime}$ hama, with final $\langle>>$, in Early Judaeo-Persian, where the final short vowel is confirmed by the formally plural equivalents hmg'n hamagan, hmgyn hamagin and especially its combination with the third plural suffix pronoun hmšsn hama-šăn. ${ }^{81}$ Instead, it is written $\mathrm{hm}^{\mathrm{A}} \dot{\mathrm{h}}, \mathrm{hm}^{\mathrm{A}} \mathrm{h}$ in the Syro-Persian Psalter from Turfan and interpreted as bamah by Sims-Williams. ${ }^{82}$ The palatal vocalisation in the first syllable represents a weakened pronunciation of pretonic $a$.

AH $23 \mathrm{~b}^{\mathrm{A}} \mathrm{d}^{\overline{\mathrm{I}}} \mathrm{yd}^{\overline{\mathrm{A}}}{ }^{\mathrm{r}} \mathrm{r}$ padidar 'the one who begets.' The manuscript reading can scarcely be taken at face value to obtain an all too obvious Ba didàr-i tu guftam: 'išq-as 'On my visit to you I said: He is love,' though this is presumably how the copyist understood the spelling he must have found in his source and copied as such. In the source manuscript, $p$ was likely written $<\mathrm{b}\rangle$ as in other Syro-Persian texts on the model of Arabic (which has no $p$ ): thus, $<\mathrm{b}>$ represents both $b$ and $p$ in manuscripts Mingana Syr. 520 (MT 8b byk payk 'apostle' beside PS 3 psr pisar 'son') and Sachau 73 (Mt 23.29 by

${ }^{80}$ Walter B. Henning, "Persian poetical manuscripts from the time of Rūdakī," in A locust's leg: Studies in honour of S. H. Taqizadeh (London: Percy Lund, Humphries and Co., 1962), 101, 103-104.

${ }^{81}$ See Paul, A grammar of Early Judaeo-Persian, 104 \120 and 88 \100 (b) respectively.

82 See n. 28. 
paygimbarān 'prophets,' $35 \mathrm{~b}^{\mathrm{A}} \mathrm{k}$ päk 'righteous'), where the value $p$ is only occasionally made clear by the addition of the subscript Arabo-Persian three-dot diacritic (Mt $23.35 \mathrm{~b}^{\mathrm{u}} \mathrm{s}^{\alpha} \mathrm{r}$ pusar 'son'), ${ }^{83}$ while $<\mathrm{p}>$ mostly represents $f$. Since manuscript $\mathrm{C}$ otherwise uses $<\mathrm{p}>$ for $p$, it is conceivable that the copyist, unable to understand properly the spelling $b^{A} \mathrm{~d}^{\bar{I}} \mathrm{yd}^{\bar{A}} \mathrm{r}$ of his source originally meant to represent padidàr, kept it without changing $\mathrm{b}$ - into $\mathrm{p}$ - according to his own spelling habits. As for padidär, this might be, in principle, the adjective meaning 'manifest, visible' (< Middle Persian pad didàr 'visible' $\leftarrow$ 'in sight' $)^{84}$ and synonymous with padid and paydà in the special meaning 'born, conceived' referred to Jesus (see above on $\mathrm{AH}$ $7 \mathrm{p}^{\mathrm{A}} \mathrm{yd}^{\bar{A} \supset \mathrm{A}} \mathrm{s}$ payd $\left.\bar{a}-\mathrm{s}\right)$. This would result in a translation of verse 23 as 'I have announced (that) the one conceived in you (i.e. Jesus) is love.' However, it seems preferable to understand padidar here as a spoken and poetic shortened form of the compound substantive padid-âvar 'the one who creates, generates'-referring to the Father-from the verbal periphrasis padìd àvardan 'to generate' equivalent to paydā kardan, paydā àvardan 'to bring into existence, create; to bear, give birth to' and belongs to the semantic sphere of conception (cf. above on AH $7 \mathrm{p}^{\mathrm{A}} \mathrm{yd}^{\overline{\mathrm{A}}) \mathrm{A}} \mathrm{s}$ paydā-s is conceived'). ${ }^{85}$ The resulting translation 'I have announced (that) the one who begets in you is love,' which parallels a passage in stanza 35 of the Syriac Dialogue between Mary and the Ange ${ }^{\beta 6}$ and is in line with the Gospel narrative in $\mathrm{Lk} 1.35$, provides a sound conclusion to a hymn relating Gabriel's annunciation to the Virgin.

83 Maggi, “A Syro-Persian version of Matthew 23.29-35,” esp. 642.

${ }^{84}$ Hasandust, Farhang-e rišešsenāxti-ye zabān-e Färsi, vol. 2, 643.

85 See Dehxodā, Loğatnāme, s.vv. padìd-ār, padìd āvardan; Mo in, Farhange Fārsi, vol. 1, 709 s.v. padìd-ār, 710 s.v. padìd āvardan; Anvari, Farhang-e bozorg, vol. 2, 1286-1287 s.vv. padìd (padìd àvardan), padìd-är. Cf. Filippone, "The Mazdean notions of creation and birth," 101-102 and Eadem, "Bearing a child' in Iranian," 58-60 for similar verbal periphrases with padid and connected words meaning 'to bear' and 'to be born' in other Iranian languages and dialects.

${ }^{86}$ See n. 52. 


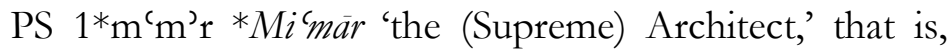
Jesus. The new variant reading $C \mathrm{~m}^{\mathrm{CA}} \mathrm{l}^{\mathrm{I}} \mathrm{ml}^{\mathrm{A}} \mathrm{r}$ may be assumed to represent the Turkish plural of mu 'allim 'teacher,' which, as Peter Zieme informs us, ${ }^{87}$ occurs in the same spelling (with the addition of the possessive suffix $-y$ ) in a Turkish text in Syriac script in CCM 398 245r7 = Mingana 469 ${ }^{88} 114 \mathrm{~b} 8$ mu'allimleri fikere dïsti 'His (?) teachers fell into thought.' The same reading seems to be mirrored by the variants $A B m^{\prime} m^{\prime} l r$ and $Z m^{\prime} \mathrm{m}: l r$, that share the omission of the first -1- though $\mathrm{Z}$ preserves the tašdìd originally belonging precisely to it. However, even if the manuscript tradition presents us with an intended reading mu'allimler 'teachers,' this can only be regarded as a lectio facilior that does not fit the syntax and goes back to someone who was not at home with Persian and copied the text in a region where Turkish was spoken, if it was not the copyist's own language: an inflected Turkish word is unexpected and unparalleled in Syro-Persian texts. Accordingly, we prefer to keep to the tentative emendation and interpretation we proposed in the first edition of the text.

PS 3 hmgwn hamgün 'in the same way (as the Fater).' On account of the obscurity of this short text, we tentatively keep to our first transcription and interpretation of this word as an adverb meaning 'likewise', ${ }^{89}$ though manuscripts $\mathrm{C}$ and $\mathrm{Z}$ now offer the spelling hmjwn hamcün 'thus' (cf. on AH 8, 10 $\mathrm{h}^{\mathrm{A}} \mathrm{mj}^{\mathrm{U}}$ wn hamcūn above), which would results in a translation of the verse as 'The Son is seated thus' (see next on nišastas) or 'The Son has thus accessed the throne (of God). ${ }^{, 0}$

PS $3 \mathrm{C} \mathrm{n}{ }^{\mathrm{I}} \mathrm{s}^{\bar{A}} \mathrm{st}^{\mathrm{A}} \mathrm{s}$ nišastas 'is seated.' This is a 'true' perfect, and not only a form conditioned by the rhyme. An ancient causative nišästan 'to seat' of nišastan 'to sit,' with a long vowel

${ }^{87}$ Letter of 28 January 2017.

${ }^{88}$ See Mingana, Catalogue of the Mingana collection, vol. 1, 844.

${ }^{89}$ Maggi and Orsatti, “Two Syro-Persian hymns," 271-272, 282.

${ }^{90}$ For this special meaning of nišastan, see e.g. Mo in, Farhang-e Färsi, vol. 4, 4736 s.v.: "julūs kardan bar taxt-i salțanat va imārat [to access the throne as a sultan or an emir];" Anvari, Farhang-e bozorg, vol. 8, 8733 s.v.: "julūs kardan dar masnad va maqām-ī [to access the throne or an office]." 
in the verbal stem, is attested in Early New Persian texts, ${ }^{91}$ as well as in two Manichaean New Persian texts as nišestan with $-\bar{a}->-\bar{e}$ - (by imāla). ${ }^{92}$ However, a perfect of a causative does not seem to fit the context in PS 3. Therefore, the spelling with an apparent long vowel in the stem of $n^{I r \bar{s}} s^{A} s$, offered only by $\mathrm{C}$, is more likely to represent a further instance of the graphic fluctuation between the ptāhā $\left\langle^{\mathrm{A}}\right\rangle$ and zqāpā $\left.<^{\bar{A}}\right\rangle$ diacritics (see $\ 2$ ) and has to be read nišastas 'he is seated.'

PS $4 \mathrm{~h}^{\mathrm{a}} \mathrm{n}{ }^{*} \mathrm{~m}^{\prime} \mathrm{rd} \dot{\mathrm{g}}^{\mathrm{U}} \mathrm{wpt}^{\mathrm{A}} \mathrm{s}$ hān ${ }^{*}$ Mard guftas 'the Man (i.e. Jesus) said that.' The variant reading $C D \mathrm{y}^{\mathrm{A} / \bar{A}} \dot{\mathrm{k}} \mathrm{m}^{\mathrm{A}} \underline{\mathrm{t}}$ ( $\left(\mathrm{D} \mathrm{m}^{\mathrm{I}} \underline{\mathrm{t}} \mathrm{l} !\right)$ $\dot{\mathrm{g}}^{\mathrm{U}} \mathrm{w} \dot{\mathrm{p}} \mathrm{t}^{\mathrm{A}} \mathrm{s}$ yak masal (D misll.) guftas 'he said a parable' looks like a lectio facilior, where the replacement of hain by yak depends on the similarity of the Syriac letter combinations $<$ hn $>\boldsymbol{N}(\mathrm{ABZ})$ and $<y k>\sim(C)$. The variant reading $A B Z m^{\prime} \mathrm{dr}$ exhibits the frequent interchange of the similar Syriac letters $<\mathrm{d}>$ a and $<\mathrm{r}\rangle \mathbf{j}$ and ālap for short $a$ occasionally found elsewhere in Syro-Persian texts ${ }^{93}$ or is a deliberate spelling of mädar 'mother' (?), likewise a lectio facilior.

\section{REFERENCES}

Anvari, Hasan. Farbang-e bozorg-e Soxan. Tehrān: Entešārāt-e Soxan. Vols. 1-8, 1381/2002; Supplement, 1389/2010.

${ }^{91}$ Dehxodā, Loǵatnāme, s.v.; Walter B. Henning, "Das Verbum des Mittelpersischen der Turfanfragmente" (Zeitschrift für Indologie und Iranistik 9 [1933]), 212. Besides nišastan, there is an alternative causative nišäxtan, which is the only one used by Firdawsī: see Fritz Wolff, Glossar zu Firdosis Schahname (Berlin: Reichsdruckerei, 1935), 809.

${ }^{92}$ See nš(y) [stn] in manuscript M 877, A /V/1/ (Werner Sundermann, "Ein manichäischer Bekenntnistext in neupersischer Sprache," in Études irano-aryennes offertes à Gilbert Lazard," ed. C.H. de Fouchécour and Ph. Gignoux [Paris: Association pour l'Avancement des Études Iraniennes, 1989], 358 with note 16) and (bn)šyst in M 581, 1. 10 (Henning, "Persian poetical manuscripts from the time of Rūdakī," 94). See also Paola Orsatti, Appunti per una storia della lingua neopersiana, vol. 1, Parte generale; fonologia; la più antica documentazione (Roma: Nuova Cultura, 2007), 167.

${ }^{3}$ Cf. e.g. Maggi and Orsatti, “Two Syro-Persian hymns," 258-259. 
Brock, Sebastian P. Bride of light: Hymns on Mary from the Syriac churches, rev. ed. Piscataway: Gorgias Press, 2010.

de Blois, François. "Glossary to the New Persian texts in Manichaean script." In Dictionary of Manichaean texts. Vol. 2: Texts from Iraq and Iran (Texts in Syriac, Arabic, Persian and Zoroastrian Middle Persian), ed. François de Blois and Nicholas Sims-Williams, compiled by François de Blois, Erica C. D. Hunter, and Dieter Taillieu. Turnhout: Brepols, 2006.

Dehxodā, 'Ali Akbar. Logatnāme, ed. Moḥammad Mo'in and Jaçar Šahidi. Tehrān: Dānešgāh-e Tehrān, 13241359/1946-1981, 222 fascicles.

De Strycker, Émile. La forme la plus ancienne du Protévangile de Jacques: Recherches sur le Papyrus Bodmer 5, avec une édition critique du texte grec et une traduction annotée. Bruxelles: Société des Bollandistes, 1961.

Durkin-Meisterernst, Desmond. Dictionary of Manichaean Middle Persian and Parthian. Turnhout: Brepols, 2004.

Ehrman, Bart D. and Zlatko Pleše. The apocryphal gospels: Texts and translations. Oxford: Oxford University Press, 2011.

Filippone, Ela. "The Mazdean notions of creation and birth: Some reflexes in the Iranian languages." In Religious themes and texts of pre-Islamic Iran and Central Asia: Studies in honour of Professor Gherardo Gnoli on the occasion of his 65th birthday on 6th December 2002, ed. Carlo G. Cereti, Mauro Maggi and Elio Provasi. Wiesbaden: Ludwig Reichert, 2003.

"Bearing a child' in Iranian." In One for the earth: Prof. Dr. Y. Mahyar Nawabi memorial volume, ed. Mahmoud Jaafari-Dehaghi. Tehran: Centre for the Great Islamic Encyclopaedia, 2008.

Grohmann, Adolf. Arabische Paläographie. II. Teil, Das Schriftwesen; die Lapidarschrift. Graz: Böhlau, 1971.

Hägg, Thomas and Bo Utas. The Virgin and her Lover: Fragments of an ancient Greek novel and a Persian epic poem. Leiden: Brill, 2003. 
Hasandust, Moḥammad. Farhang-e rišešenāxti-ye zabān-e Fārsi. Tehrān: Farhangestān-e Zabān va Adab-e Fārsi, 1393/2014, 5 vols.

Henning, Walter B. "Das Verbum des Mittelpersischen der Turfanfragmente." Zeitschrift für Indologie und Iranistik 9 (1933): 158-235.

"Persian poetical manuscripts from the time of Rūdakī." In A locust's leg: Studies in honour of S. H. Taqizadeh. London: Percy Lund, Humphries and Co., 1962.

The holy Bible: New revised standard version containing the Old and New

Testaments. Cambridge: Cambridge University Press, 1989.

Kiraz, George Anton. Türrāṣ Mamllä: A grammar of the Syriac language. Vol. 1: Orthography, Piscataway: Gorgias Press, 2012.

Lazard, Gilbert. La langue des plus anciens monuments de la prose persane. Paris: Klincksieck, 1963.

"Remarques sur le fragment judéo-persan de Dandān-Uiliq." In A green leaf: Papers in honour of Professor Jes P. Asmussen. Leiden: Brill, 1988 (repr. in Gilbert Lazard. La formation de la langue persane. Paris: Peeters, 1995).

- Grammaire du persan contemporain, nouvelle éd. avec la collaboration de Yann Richard, Rokhsareh Hechmati et Pollet Samvelian. Téhéran: Institut français de recherche en Iran, 2006.

"Poetry, iv: Poetics of Middle Persian." In Encyclopaedia Iranica, online ed. 2006 (available at www.iranica.com/articles/poetry-iv-poetics-of-middlepersian).

MacKenzie, David N. "The language of the Medians." Bulletin of the School of Oriental and African Studies 22 (1959): 354-355 (repr. in David N. MacKenzie. Iranica diversa, ed. Carlo G. Cereti and Ludwig Paul. Vol. 2. Roma: Istituto italiano per l'Africa e l'Oriente, 1999).

"An Early Jewish-Persian argument." Bulletin of the School of Oriental and African Studies 31:2 (1968): 249-269. 
. "An index to 'An Early Jewish-Persian argument'." In The Persian language in history, ed. Mauro Maggi and Paola Orsatti. Wiesbaden: Ludwig Reichert, 2011.

Maggi, Mauro. "A Syro-Persian version of Matthew 23.29-35." In Scritti in onore di Giovanni M. D'Erme, ed. Michele Bernardini and Natalia L. Tornesello. Vol. 1. Napoli: Università degli studi di Napoli L'Orientale, 2005.

Maggi, Mauro and Paola Orsatti. "Two Syro-Persian hymns for Palm Sunday and Maundy Thursday.” In The Persian language in history, ed. Mauro Maggi and Paola Orsatti. Wiesbaden: Ludwig Reichert, 2011.

McCollum, Adam C. "Syro-Georgian Trisagion." At http://hmmlorientalia.wordpress.com/2013/10/24/syrogeorgian-trisagion.

. "Garshuni as it is: Some observations from reading East and West Syriac manuscripts." Hugoye: Journal of Syriac studies 17:2 (2014): 215-235.

Meier, Fritz. "Aussprachefragen des älteren Neupersisch." Oriens 27-28 (1981): 70-176 (repr. in Fritz Meier. Bausteine: Ausgewälte Ausfätre zur Islamwissenschaft, ed. E. Glassen and G. Schubert. Vol. 2. Stuttgart: Steiner, 1992).

Mingana, Alphonse. Catalogue of the Mingana collection of manuscripts, now in the possession of the Trustees of the Woodbrooke Settlement, Selly Oak, Birmingham. Vol. 1: Syriac and Garshüni manuscripts. Cambridge: Heffer and Sons, 1933.

Mo in, Mohammad. Farhang-e Färsi-ye motavasseț, 7th ed. Tehrān: Amir Kabir, 1364/1985, 6 vols.

Orsatti, Paola. "Syro-Persian formulas in poetic form in baptism liturgy." In Persian origins: Early Judaeo-Persian and the emergence of New Persian: Collected papers of the symposium, Göttingen 1999, ed. Ludwig Paul. Wiesbaden: Harrassowitz, 2003.

- Appunti per una storia della lingua neopersiana. Vol. 1: Parte generale; fonologia; la più antica documentazione. Roma: Nuova Cultura, 2007.

Paul, Ludwig. "Early Judaeo-Persian in a historical perspective: The case of the prepositions $b e, u, p a(d)$, and the suffix rä." 
In Persian origins: Early Judaeo-Persian and the emergence of New Persian: Collected papers of the symposium, Göttingen 1999, ed. Ludwig Paul. Wiesbaden: Harrassowitz, 2003.

- A grammar of Early Judaeo-Persian. Wiesbaden:

Ludwig Reichert, 2013.

Provasi, Elio. "New Persian texts in Manichaean script from Turfan." In The Persian language in history, ed. Mauro Maggi and Paola Orsatti. Wiesbaden: Ludwig Reichert, 2006.

Rubinčik, Ju. A. Grammatika souremennogo persidskogo literaturnogo jasykea. Moskva: Vostočnaja literatura, 2001.

Scarcia, Gianroberto. "A preliminary report on a Persian legal document of 470-1078 found at Bāmiyān." East and West 14:1-2 (1963): 73-81.

"An edition of the Persian legal document from Bāmiyān." East and West 16:3-4 (1966): 290-295.

Scher, Addai. "Notice sur les manuscrits syriaques et arabes conservés à l'archevêché chaldéen de Diarbékir." Journal asiatique 10 (1907): 331-362, 385-431.

"Notice sur les manuscrits syriaques et arabes conservés dans la bibliothèque de l'évêché chaldéen de Mardin." Revue des bibliothèques 18 (1908): 64-95.

Sokoloff, Michael. A Syriac lexicon: A translation from the Latin, correction, expansion, and update of $C$. Brockelmann's Lexicon Syriacum. Winona Lake: Eisenbrauns, 2009.

Sundermann, Werner. "Ein manichäischer Bekenntnistext in neupersischer Sprache." In Études irano-aryennes offertes à Gilbert Lazard, ed. C.-H. de Fouchécour and Ph. Gignoux. Paris: Association pour l'Avancement des Études Iraniennes, 1989.

Takahashi, Hidemi. "Armenian Garshuni: An overview of the known material." Hugoye: Journal of Syriac studies 17:1 (2014): 81-117.

"Armenisch-Garschuni (Armenisch in syrischer Schrift)," in Johannes den Heijer, Andrea Schmidt, and Tamara Pataridze (eds.), Scripts beyond borders: A survey of allographic traditions in the Euro-Mediterranean world, Leuven: Peeters, 2014. 
"Armenian Garshuni (Armenian in Syriac characters) and its users." In Syriac in its multi-cultural context: First international Syriac studies symposium, Mardin Artuklu University, Institute of Living Languages, 20-22 April 2012, Mardin, ed. Herman Teule et al. Leuven: Peeters, 2017. "The hymn 'O filii' in Syriac transcription," forthcoming [draft of 31 January 2014].

Wolff, Fritz. Glossar zu Firdosis Schahname. Berlin: Reichsdruckerei, 1935. 
